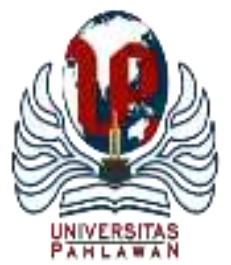

Edukatif : Jurnal Ilmu Pendidikan Volume 4 Nomor 1 Tahun 2022 Halm 411 - 435 EDUKATIF: JURNAL ILMU PENDIDIKAN

Research \& Learning in Education

https://edukatif.org/index.php/edukatif/index

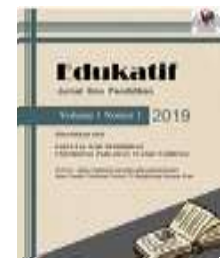

\title{
Pendekatan Ekokultural pada Model Rancangan Pangkalan Perahu Tanggap Bencana di Kawasan Pesisir Kota Manado
}

\author{
Reny Syafrini ${ }^{1}$, Sangkertadi ${ }^{2}$, Rachmat Prijadi ${ }^{3}$, Valeria Theresia Woy ${ }^{4 凶}$ \\ Universitas Sam Ratulangi, Indonesia ${ }^{1,2,3,4}$ \\ E-mail : renysyafrini@ unsrat.ac.id ${ }^{1}, \underline{\text { sangkertadi@unsrat.ac.id }}^{2}$, rachmatprijadi@unsrat.ac.id $^{3}$, \\ valeriatheresiawoy@dosenlb.unsrat.ac.id ${ }^{4}$
}

\begin{abstract}
Abstrak
Kawasan pesisir Kota Manado berkali-kali mengalami dampak dari gelombang pasang dan angin kencang yang sering menyebabkan kerusakan kapal dan peralatan kerja bagi masyarakat nelayan yang bermukim dan bernelayan di daerah pesisir Kota Manado. Untuk itu perlu dilakukan penelitian lebih lanjut agar dapat mengidentifikasi dampak-dampak yang ditimbulkan serta mendapatkan alternatif solusi untuk meminimalisir dampak bencana bagi para nelayan. Penelitian ini menggunakan metode kualitatif dengan pendekatan ekokultural. Observasi langsung dilakukan untuk mengidentifikasi dampak bencana yang ditimbulkan dan pendekatan ekokultural dipakai untuk mengidentifikasi budaya bermukim dan bernelayan masyarakat. Hasil penelitian menunjukkan adanya beberapa upaya masyarakat dalam mengantisipasi gelombang pasang dan angin kencang dengan membuat pemecah ombak dan tiang deteksi gelombang air laut, namun belum maksimal untuk meminimalisir kerusakan. Selain itu, pendekatan ekokultural menunjukkan adanya perbedaan budaya bermukim dan bernelayan pada setiap titik pangkalan perahu. Penelitian ini kemudian dilanjutkan dengan mendesain membuat simulasi pangkalan perahu yang memiliki jalur dan tempat evakuasi untuk meminimalisir dampak kerusakan. Desain pangkalan perahu disesuaikan dengan pola aktivitas masyarakat nelayan di kawasan pesisir Kota Manado. Kesimpulannya, penataan ruang pangkalan perahu yang ideal, modifikasi fasilitas sosial dan penambahan jalur evakuasi dapat meminimalisir dampak bencana yang sering terjadi. Desain ini menjadi inovasi tanggap bencana dari model rancangan pangkalan perahu dengan pendekatan ekokultural.
\end{abstract}

Kata Kunci: kawasan pesisir, iklim tropis, ekokultural, pangkalan perahu, nelayan

\begin{abstract}
The coastal area of Manado City has repeatedly experienced the impact of tidal waves and strong winds which often cause damage to ships and work equipment for fishing communities who live and fish in the coastal areas of Manado. For this reason, it is necessary to conduct further research in order to identify the impacts and obtain alternative solutions to minimize the impact of disasters for fishermen. This study uses a qualitative method with an eco-cultural approach. Direct observation is carried out to identify the impact of the disaster caused and an eco-cultural approach is used to identify the culture of living and fishing in the community. The results of the study indicate that there are several community efforts in anticipating tidal waves and strong winds by making breakwaters and sea wave detection poles, but they have not been maximized to minimize damage. The eco-cultural approach shows that there are cultural differences between living and fishing at each point of the boat base. This research is then continued by designing a simulation of a boat base that has evacuation routes and places to minimize the impact of damage. The design of the boat base is adapted to the activity patterns of fishing communities in the coastal area of Manado. In conclusion, an ideal boat base spatial arrangement, modification of social facilities and the addition of evacuation routes can minimize the impact of disasters that often occur. This design is a disaster response innovation from a boat base design model with an ecocultural approach.
\end{abstract}

Keywords: coastal area, tropical climate, eco-cultural, boatyard, fisherman

Copyright (c) 2022 Reny Syafrini, Sangkertadi, Rachmat Prijadi, Valeria Theresia Woy

$\triangle$ Corresponding author

Email : valeriatheresiawoy@dosenlb.unsrat.ac.id

DOI : https://doi.org/10.31004/edukatif.v4i1.1850

ISSN 2656-8063 (Media Cetak)

ISSN 2656-8071 (Media Online) 
412 Pendekatan Ekokultural pada Model Rancangan Pangkalan Perahu Tanggap Bencana di Kawasan Pesisir Kota Manado - Reny Syafrini, Sangkertadi, Rachmat Prijadi, Valeria Theresia Woy

DOI: https://doi.org/10.31004/edukatif.v4i1.1850

\section{PENDAHULUAN}

Permukiman di kawasan pesisir Kota Manado masih didominasi oleh hunian masyarakat yang berprofesi sebagai nelayan. Nelayan subsisten menggantungkan hidup dari menangkap ikan di perairan pantai Kota Manado. Menurut Kurnia (Kurnia et al., 2019) terdapat 8 aribut pelayanan tambatan perahu yang dianggap telah memenuhi kepuasan melayan yaitu keberadaan penerima keluhan, kecepatan perbaikan fasilitas, keterampilan petugas melayani, kemudahan prosedur pemesanan, penampilan petugas, harga yang ditetapkan, kondisi kebersihan dan kondisi keamanan. Namun hal itu hanya berlaku bagi tambatan yang disediakan oleh pemerintah dalam hal ini adalah pihak pelabuhan. Para nelayan di kawasan pesisir Kota Manado pada umumnya menyandarkan perahu pada tambatan-tambatan perahu yang dibuat secara tradisional disepanjang pesisir Kota Manado. Lokasi tambatan terbagi pada beberapa titik disepanjang kawasan pesisir Kota Manado dan terbagi atas beberapa organisasi kelompok nelayan. Anggota organisasi kelompok nelayan sering melaksanakan aktivitas bersama pada sekretariat yang dibangun secara tradisional di sekitar kawasan tambatan perahu seperti beribadah bersama, bercengkerama, berdiskusi dengan pemerintah serta pengunjung dan lain sebagainya. Sekretariat kelompok nelayan di kawasan pesisir Kota Manado umumnya hanya berupa bangunan dengan penyanggah beberapa kolom dan menggunakan penutup atap. Luas ruang sekretariat juga rata-rata $6 \mathrm{~m}^{2}$ sampai $12 \mathrm{~m}^{2}$. Sekretariat tidak hanya berfungsi sebagai ruang sosial para nelayan tetapi juga sebagai ruang penyimpanan peralatan kerja para nelayan. Dalam kehidupan kesehariannya, masyarakat nelayan berinteraksi dengan baik dan lancar serta senantiasa bekerja sama dalam berbagai wujud. Interaksi tersebut tidak saja antar sesame nelayan tetapi juga antara nelayan dan lingkungan diluar komunitas nelayan (Rifaldi et al., 2018). Para nelayan selalu bergotong royong untuk terus mengembangkan pangkalan perahu dan juga untuk mengamankan perahu-perahu saat terjadi bencana gelombang pasang dan angin kencang yang disebabkan oleh perubahan cuaca ekstrim yang sering terjadi di kawasan pesisir Kota Manado.

Dinamika kawasan pesisir merupakan suatu perubahan yang terjadi pada ruang maupun waktu tertentu yang disebabkan oleh faktor tenaga dari dalam bumi (endogen) dan tenaga dari luar bumi (eksogen) termasuk dalam hal ini faktor kegiatan manusia. Dinamika kawasan pesisir tidak hanya dipengaruhi oleh faktor alam baik dari darat maupun dari laut tetapi disebabkan juga oleh kegiatan manusia yang mempengaruhi lingkungan seperti reklamasi pantai, kegiatan pertanian, pembangunan pelabuhan dan permukiman pesisir yang semuanya menjadi tipologi buatan manusia (Putranto, 2020). Perkembangan kawasan pesisir Kota Manado juga mengalami dinamika kawasan pesisir yang tebentuk dari faktor alam dan manusia dan menjadi penyebab sering terjadinya bencana gelombang pasang dan angin kencang di kawasan pesisir Kota Manado.

Bencana badai pesisir akibat perubahan iklim meningkat dan telah banyak diantisipasi melalui penanaman hutan bakau seperti yang sudah dilakukan masyarakat pesisir di berbagai kota dekat pantai (Santoso et al., 2019). Penanaman hutan bakau yang hanya ada pada beberapa titik dan pembuatan beberapa pemecah ombak disepanjang kawasan pesisir Kota Manado masih membuat penanggulangan akan bencana gelombang pasang dan angin kencang belum maksimal. Perubahan iklim dan perubahan lingkungan alam pada daerah pesisir Kota Manado masih sering mendatangkan berbagai persoalan seperti kerusakan harta benda bagi para nelayan. Perubahan cuaca secara tiba-tiba pada masa peralihan memberi dampak gelombang pasang dan angin kencang. Meskipun sudah beberapa kali terjadi, dampak dari gelombang pasang dan angin kencang tidak dapat sepenuhnya diantisipasi oleh masayarakat nelayan karena kurangnya fasilitas yang dapat meminimalisisr dampak bencana serta area tambatan perahu yang belum tertata dengan baik. Kerugian utama para nelayan adalah rusaknya perahu dan peralatan kerja. Hal ini diperparah dengan aktivitas reklamasi pantai yang melakukan penimbunan batu sebagai upaya meredam kekuatan pecahan ombak di bibir pantai. Persoalan ini terus berulang terjadi sehingga dibutuhkan antisipasi masyarakat yang bermukim di kawasan pesisir Kota Manado. 
Beberapa antisipasi bencana sudah diupayakan pemerintah dan masyarakat seperti pembangunan tanggul pengaman dan pemecah ombak. Namun pada kenyataannya hal ini belum mampu meminimalisir dampak gelombang pasang dan angin kencang yang menyebabkan kerusakan perahu dan peralatan kerja nelayan. Ada tiga tahapan mendasar dalam manajemen bencana yaitu respon terhadap bencana, kesiapsiagaan menghadapi bencana dan minimalisasi (mitigasi) dampak bencana dimana ketiganya perlu dilakukan secara seimultan. Mitigasi bencana terdiri dari beberapa bagian yaitu mitigasi struktural yang merupakan upaya untuk meminimalkan bencana yang dilakukan melalui pembangunan berbagai prasarana fisik dan menggunakan teknologi sedangkan mitigasi non struktural yaitu melalui perundang-undangan, pelatihan serta mitigasi kultural adalah pengendalian dan pencegahan bencana yang dilakukan dengan budaya dan tradisi masyarakat lokal (Triana et al., 2017).

Penelitian - penelitian sebelumnya terkait pangkalan perahu lebih kepada bahasan terkait aktivitas social dan ekonomi masyarakat nelayan serta operasional bernelayan. Untuk mitigasi bencana daerah pesisir pun masih bersifat umum belum ada yang secara spesifik membahas dampak bencana pada pangkalanpangkalan perahu yang ada di kawasan pesisir pantai. Untuk itu dibutuhkan penelitian lebih lanjut untuk mengidentifikasi dampak-dampak yang ditimbulkan akibat bencana dalam hal ini bencana kawasan pesisir yang sering terjadi di Kota Manado yaitu gelombang pasang dan angin kencang. Penelitian ini dilakukan untuk mendapatkan alternatif solusi bagi pangkalan perahu kawasan pesisir agar dapat meminimalisir dampak bencana bagi para nelayan yang bermukim di kawasan pesisir.

Saat ini pembangunan ruang pesisir lebih mengutamakan fasilitas publik seperti ruang sosial dan pembangunan infrastruktur sehingga memarginalkan masyarakat nelayan tradisional yang juga bermukim di kawasan pesisir Kota Manado. Meskipun pembangunan reklamasi mendatangkan respon positif dari sebagian besar masyarakat termasuk nelayan, namun perhatian pemerintah terhadap kondisi ruang hidup komunitas nelayan ini masih belum mendapat prioritas bagi para penentu kebijakan spasial perkotaan. Perbaikan kondisi lingkungan masyarakat marginal akan mendorong perencanaan inklusif yang merepresentasikan keragaman dan keseimbangan ruang hidup di daerah perkotaan khususnya di Kota Manado.

Ekokultural merupakan pendekatan perancangan yang berorientasi pada keseimbangan alam dan budaya. Menurut Amri et al, (2021), pengetahuan lokal berfungsi untuk mencerna sejumlah pengetahuan global dan mengkonversikannya menjadi nutrisi lokal untuk pengembangan individu dan komunitas lokal (Amri et al., 2021). Implikasinya pada budaya lokal masyarakat nelayan yang dapat mengidentifikasi dan memilah-milah mana pengetahuan atau teknologi global yang dapat diadopsi untuk kepentingan masyarakat dan komunitas dengan tetap mempertahankan nilai budaya masyarakat yang sudah melekat dan menjadi ciri khas masyarakat dalam aktivitas bermukim dan bernelayan. Pendekatan ekokultural digunakan untuk mengidentifikasi aktivitas masyarakat nelayan yang bermukim di kawasan pesisir Kota Manado. Aktivitas masyarakat nelayan ini mempengaruhi penataan ruang pangkalan perahu dimana di setiap pangkalan perahu memiliki sekretariat sebagai ruang sosial para anggota kelompok nelayan. Logika eko kultural digunakan sebagai pendekatan rancangan pangkalan perahu sebagai bentuk keberlanjutan perancangan arsitektur yang berbasis teknik universal sehingga sering gagal dalam penerapannya pada beberapa lokasi dan masyarakat tertentu. Pendekatan eko kulturural dalam rancangan arsitektur menggunakan aktivitas harian masyarakat sebagai unit analisis dengan menekankan aspek penggunaan ruang dan dipadukan dengan analisis ekoregional yang mencerminkan kondisi fisik lingkungan dan iklim mikro lokal yang membentuk formasi spasial. Pendekatan ini diharapkan dapat membentuk suatu permodelan pangkalan perahu kawasan pesisir Kota Manado yang lebih adaptif dengan lingkungan alam sehingga dapat mengurahi dampak kerugian yang sering dialami oleh masyarakat nelayan. Dalam penelitian ini permasalahan mencakup:

1. Aktivitas lingkungan sosial masyarakat nelayan kawasan pesisir Kota Manado yang mempengaruhi penataan kebutuhan ruang.

2. Identifikasi dampak bencana gelombang pasang dan angin kencang di kawasan pesisir Kota Manado. 
414 Pendekatan Ekokultural pada Model Rancangan Pangkalan Perahu Tanggap Bencana di Kawasan Pesisir Kota Manado - Reny Syafrini, Sangkertadi, Rachmat Prijadi, Valeria Theresia Woy

DOI: https://doi.org/10.31004/edukatif.v4i1.1850

3. Upaya antisipasi terhadap kerusakan kapal dan peralatan kerja para nelayan akibat gelombang pasang dan angin kencang berupa rancangan model pangkalan perahu tanggap bencana dengan pendekatan ekokultur.

\section{METODE PENELITIAN}

Penelitian ini mengunakan metode kualitatif dengan model penelitian dan pengembangan. Penelitian dan pengembangan adalah suatu proses atau Langkah-langkah untuk mengembangkan suatu produk baru atau menyempurnakan produk yang sudah ada sebelumnya (Sepriana et al., 2019). Penelitian dilakukan terlebih dahulu dengan mengidentifikasi aktivitas sosial para nelayan dan dampak-dampak kerusakan akibat bencana pada beberapa tahun terakhir. Pengambilan data dilakukan dengan metode observasi dan dokumentasi yang dilakukan pada 9 titik pangkalan perahu yang ada di kawasan pesisir Kota manado budaya bermukim dan bernelayan berbeda-beda. Nelayan memberikan informasi tambahan lewat wawancara terkait pola aktivitas keseharian mereka dan dampak-dampak yang ada akibat gelombang pasang dan angin kencang. Hasil penelitian ini kemudian dilanjutkan dengan metode pengembangan dalam hal ini metode perancangan untuk menghasilkan alternatif solusi dari segi arsitektural berupa permodelan arsitektur pangkalan perahu yang tanggap bencana.

Pendekatan perancangan mengambil sistem arsitektur berkelanjutan dengan menggunakan logika eko kultural yang menekankan reorientasi fundamental nilai-nilai yang mengedepankan aspek lingkungan fisik dan budaya masyarakat nelayan kawasan pesisir Kota Manado dengan terus melestarikan keragaman budaya yang ada. Perancangan berdasarkan hasil survei dan analisis dibuat dengan software autocad dan Lumion. Hasil perancangan kemudian dibuat simulasi lewat animasi Lumion yang menggambarkan cara-cara evakuasi perahu saat terjadi gelombang pasang dan angin kencang di kawasan pesisir Kota Manado. Animasi simulasi dilakukan kurang lebih 3 kali perbaikan hingga mendapatkan nilai rata-rata 7,8 dengan skala baik dari segi desain tanggap bencana dari sesama rekan arsitek dan nilai rata-rata 8,9 dengan skala sangat baik oleh para nelayan dalam setiap kelompok nelayan yang menjadi narasumber utama.

\section{HASIL DAN PEMBAHASAN PENELITIAN}

\section{Hasil Identidikasi Objek}

Observasi kegiatan nelayan di sepanjang garis pantai Kecamatan Malalayang sampai pada Kecamatan Tuminting Kota Manado dilakukan pada 9 titik pangkalan perahu. Masing-masing pangkalan perahu memiliki nama komunitas kelompok nelayan. Komunitas kelompok nelayan dibentuk para nelayan agar bisa saling mengenal dan berkoordiri satu sama lain.setiap kelompok nelayan memiliki sekretariat sebagai ruang sosial bersama dan sebagai tempat berinteraksi dengan pemerintah dan tamu ketika mendapat kunjungan.

Tabel 1. Kompilasi hasil pendataan objek penelitian

\begin{tabular}{llllll}
\hline No & \multicolumn{1}{c}{ Lokasi } & $\begin{array}{c}\text { Jumlah } \\
\text { KK } \\
\text { Nelayan }\end{array}$ & $\begin{array}{c}\text { Jumlah } \\
\text { Perahu }\end{array}$ & $\begin{array}{c}\text { Luas } \\
\text { Pangkalan }\end{array}$ & \multicolumn{1}{c}{ Market } \\
\hline 1 & $\begin{array}{l}\text { Kampung } \\
\text { Kinamang }\end{array}$ & 34 & 30 & $180 \mathrm{~m}^{2}$ & Tibo \\
\hline 2 & Kampung LOS & 70 & 30 & $5200 \mathrm{~m}^{2}$ & Tibo dan Pasar Bahu \\
\hline 3 & Pangkalan Bahu & 100 & 44 & $2000 \mathrm{~m}^{2}$ & Tibo dan Pasar Bahu \\
\hline 4 & Sario Tumpaan & 112 & 112 & $1500 \mathrm{~m}^{2}$ & Tibo dan Pasar Bahu \\
\hline 5 & Jembatan Kuning & 60 & 20 & $1000 \mathrm{~m}^{2}$ & Lingkungan permukiman \\
\hline 6 & $\begin{array}{l}\text { Kompleks } \\
\text { Megamas }\end{array}$ & 90 & 60 & $2700 \mathrm{~m}^{2}$ & $\begin{array}{l}\text { Pinggir jalan dan } \\
\text { lingkungan permukiman }\end{array}$ \\
\hline
\end{tabular}


415 Pendekatan Ekokultural pada Model Rancangan Pangkalan Perahu Tanggap Bencana di Kawasan Pesisir Kota Manado - Reny Syafrini, Sangkertadi, Rachmat Prijadi, Valeria Theresia Woy

DOI: https://doi.org/10.31004/edukatif.v4i1.1850

\begin{tabular}{llllll}
\hline No & \multicolumn{1}{c}{ Lokasi } & $\begin{array}{c}\text { Jumlah } \\
\text { KK } \\
\text { Nelayan }\end{array}$ & $\begin{array}{c}\text { Jumlah } \\
\text { Perahu }\end{array}$ & $\begin{array}{c}\text { Luas } \\
\text { Pangkalan }\end{array}$ & \multicolumn{1}{c}{ Market } \\
\hline 7 & Sindulang 1 & 60 & 19 & $1640 \mathrm{~m}^{2}$ & $\begin{array}{l}\text { Pinggir jalan dan } \\
\text { lingkungan permukiman }\end{array}$ \\
\hline 8 & Bitung Karangria & 70 & 70 & $3200 \mathrm{~m}^{2}$ & Pasar ke TPI dan Tibo \\
\hline 9 & Maasing & 100 & 35 & $2600 \mathrm{~m}^{2}$ & Pinggir jalan dan TPI \\
\hline
\end{tabular}

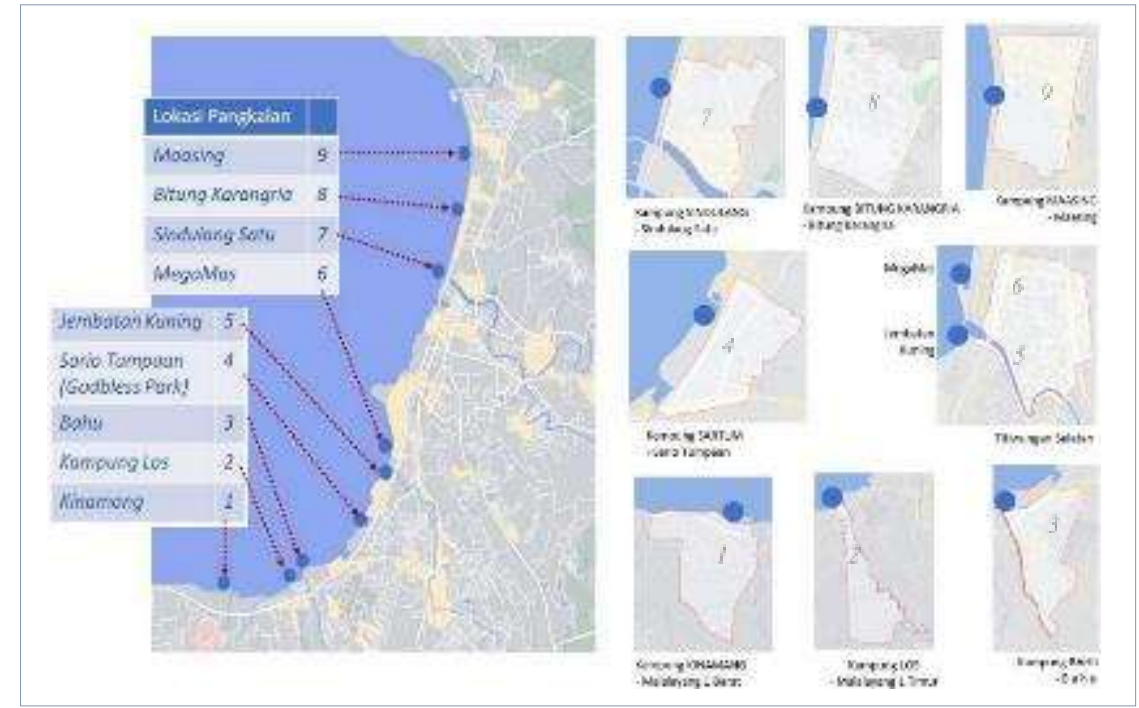

Gambar 1: Peta Sebaran Lokasi Objek Penelitian

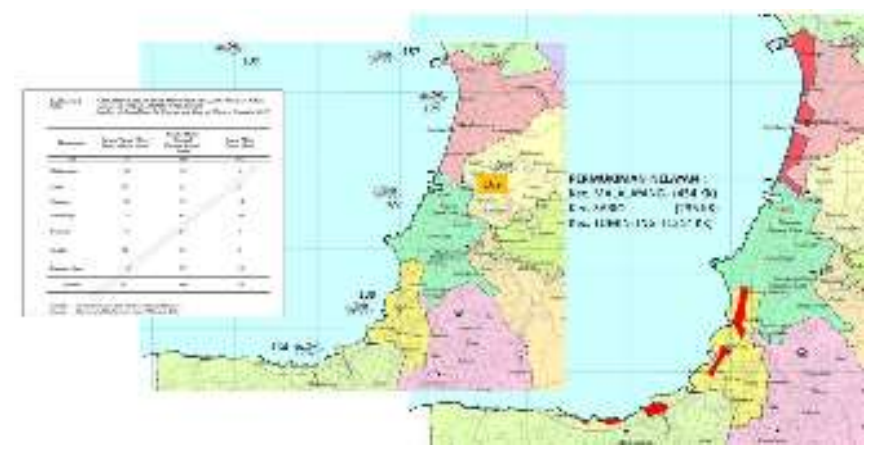

Gambar 2: Peta Sebaran Permukiman Nelayan Dan Jumlah Perahu Nelayan

\section{Pola Aktivitas/Pergerakan Harian Nelayan Kawasan Pesisir Kota Manado}

Produksi dan reproduksi kehidupan sosial sebagai pemenuhan akan kehidupan aktor di dalam masyarakat merupakan intisari dari teori strukturasi Giddens. Teori strukturasi berangkat dari tindakan dan pelaku tindakan dalam rutinitas kelangsungan kehidupan sosial. Hal ini menggambarkan keyakinan masyarakat bahwa sistem sosial dan aktor individu sama pentingnya dalam menjelaskan fenomena sosial. Melalui aktivitas hariannya, manusia modern, seperti halnya masyarakat nelayan, telah mereproduksi masyarakat, hubungan-hubungan sosial dan gagasan gagasan dari masyarakatnya; mereka mereproduksi bentuk tatanan sosial hidup harian.

Sejak pembentukan kawasan perkotaan oleh kolonial Belanda, kawasan pesisir kota Manado di dominasi oleh pemukim migran yang datang atas kemauan sendiri ataupun didatangkan oleh pemerintah Belanda untuk dipekerjakan di berbagai sektor seperti perkebunan, pelabuhan, pembangunan infrastruktur dan lain sebagainya. Khusus migran yang berasal dari kepulauan, pilihan bermukim dekat pantai menjadi opsi 
utama bagi mereka yang memiliki ketrampilan sebagai nelayan. Penelitian ini telah mengeksplorasi rutinitas kehidupan dan dinamika sosiospasial masyarakat nelayan dalam betahan hidup di permukiman pesisir kota Manado. Delapan lokasi yang menjadi bagian dari ruang hidup nelayan di pesisir kota mewakili gambaran aktivitas ekonomi yang memanfaatkan ruang laut sebagai mata pencaharian. Muara sungai menjadi arena bertahan hidup bagi sebagian masyarakat pesisir di Kota Manado.

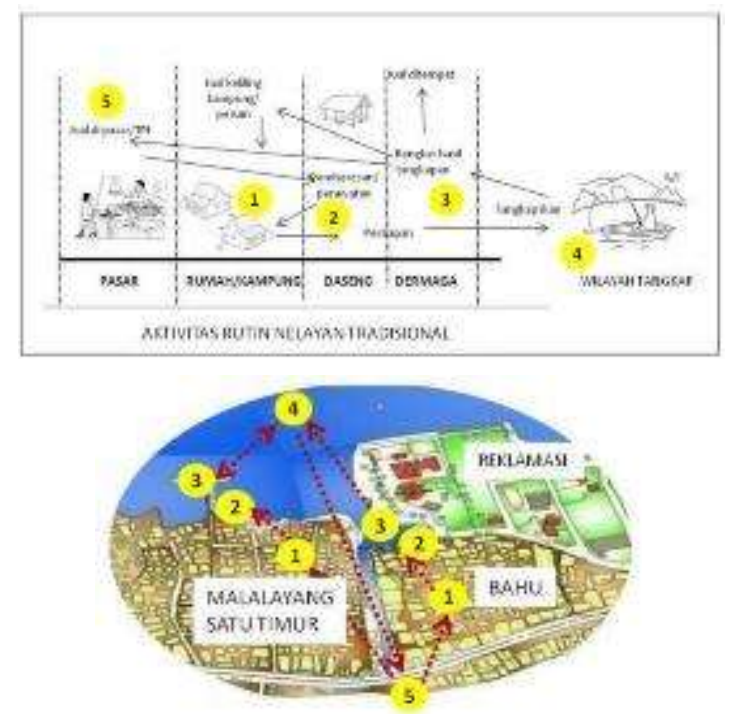

Gambar 3: Skema Pergerakan Harian Masyarakat Nelayan Kawasan Pesisir Kota Manado

Hasil analisis pergerakan harian nelayan menunjukkan tiga komponen utama yang terbangun sebagai lingkungan kehidupan kampung pantai, yakni tempat tinggal, pangkalan perahu dan ruang pasar. Ketiga komponen saling terkait satu sama lain untuk menjamin kelangsungan hidup aktivitas nelayan. Bagi kampung pantai, pangkalan perahu memainkan peranan penting sebagai properti utama yang tidak hanya sebagai tambatan perahu, juga berperan sebagai ruang sosial di mana orang berkumpul, berekpresi dan melakukan kegiatan sosial bersama-sama. Meski mengalami berbagai hambatan struktural, lokasi penelitian menunjukkan bahwa masyarakat nelayan masih berdaya dalam mempertahankan ruang hidup ditingkat lokal, namun lemah di tingkat atas dimana penanganan oleh pemerintah yang masih kurang.

Penelitian ini mengambil lokasi pada 9 titik pangkalan perahu yang dimiliki oleh 9 kelompok nelayan dimana para nelayan yang tergabung dalam kelompok nelayan tersebut bermukim di kawasan pesisir kota Manado berdekatan dengan lokasi pangkalan perahu.

Tabel 2. Daftar Nama Komunitas Kelompok Nelayan Di Sepanjang Pesisir Kota Manado

\begin{tabular}{|c|c|c|c|c|}
\hline NO & LOKASI & AKTIVITAS PANGKALAN & $\begin{array}{l}\text { POSISI TERHADAP } \\
\text { TEMPAT TINGGAL }\end{array}$ & DOKUMENTASI \\
\hline 1 & $\begin{array}{l}\text { Kampung } \\
\text { Kinamang }\end{array}$ & $\begin{array}{l}\text { Persiapan melaut, bongkar } \\
\text { muatan, distribusi hasil } \\
\text { tangkapan, membersihkan } \\
\text { peralatan kerja, penyimpanan } \\
\text { perahu, beristirahat setelah } \\
\text { bekerja, organisasi/kumpulan, } \\
\text { kegiatan sosial (ibadah, forum } \\
\text { sosial), kerja bakti }\end{array}$ & & \\
\hline
\end{tabular}


417 Pendekatan Ekokultural pada Model Rancangan Pangkalan Perahu Tanggap Bencana di Kawasan Pesisir Kota Manado - Reny Syafrini, Sangkertadi, Rachmat Prijadi, Valeria Theresia Woy

DOI: https://doi.org/10.31004/edukatif.v4i1.1850
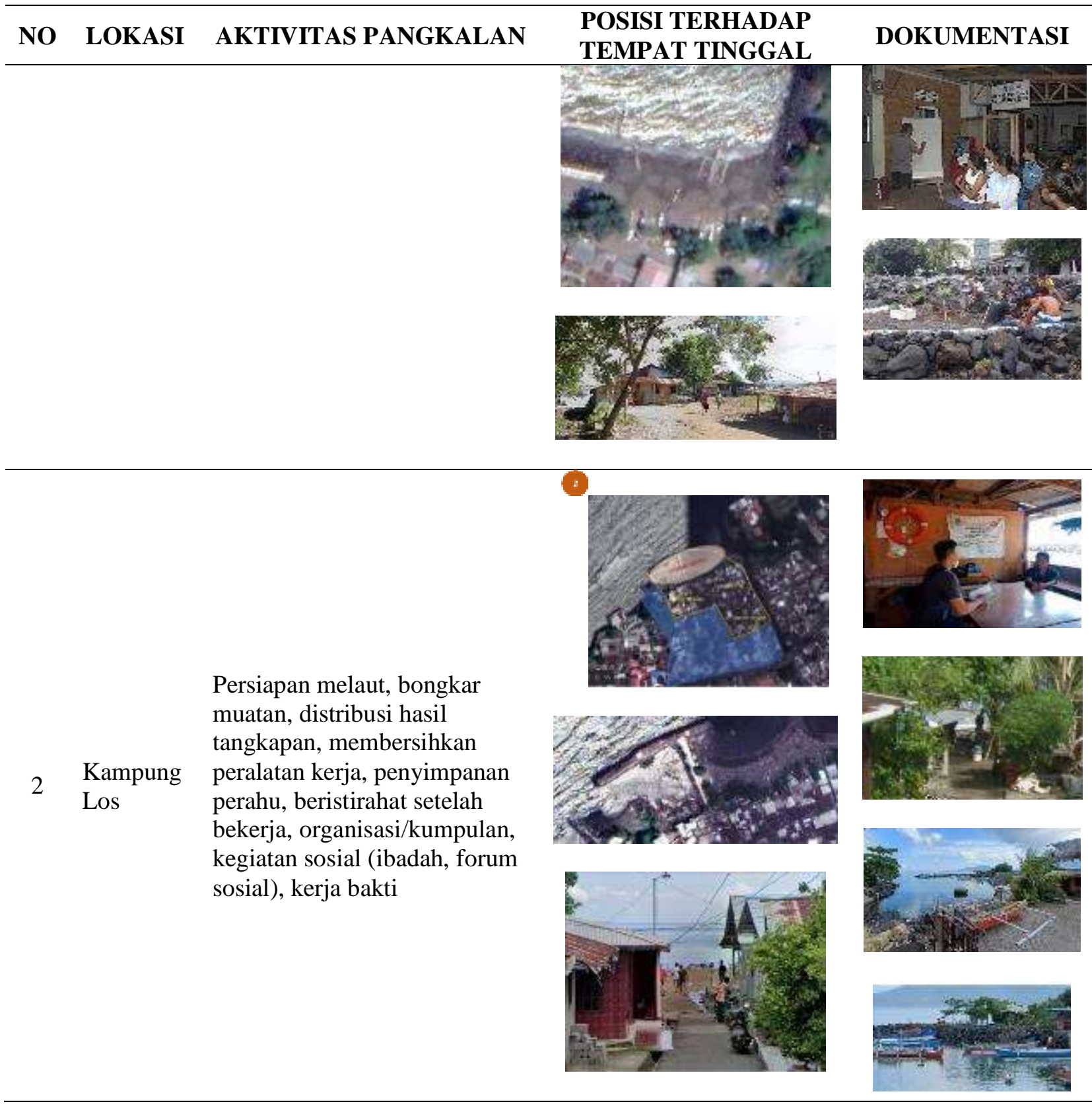
418 Pendekatan Ekokultural pada Model Rancangan Pangkalan Perahu Tanggap Bencana di Kawasan Pesisir Kota Manado - Reny Syafrini, Sangkertadi, Rachmat Prijadi, Valeria Theresia Woy

DOI: https://doi.org/10.31004/edukatif.v4i1.1850

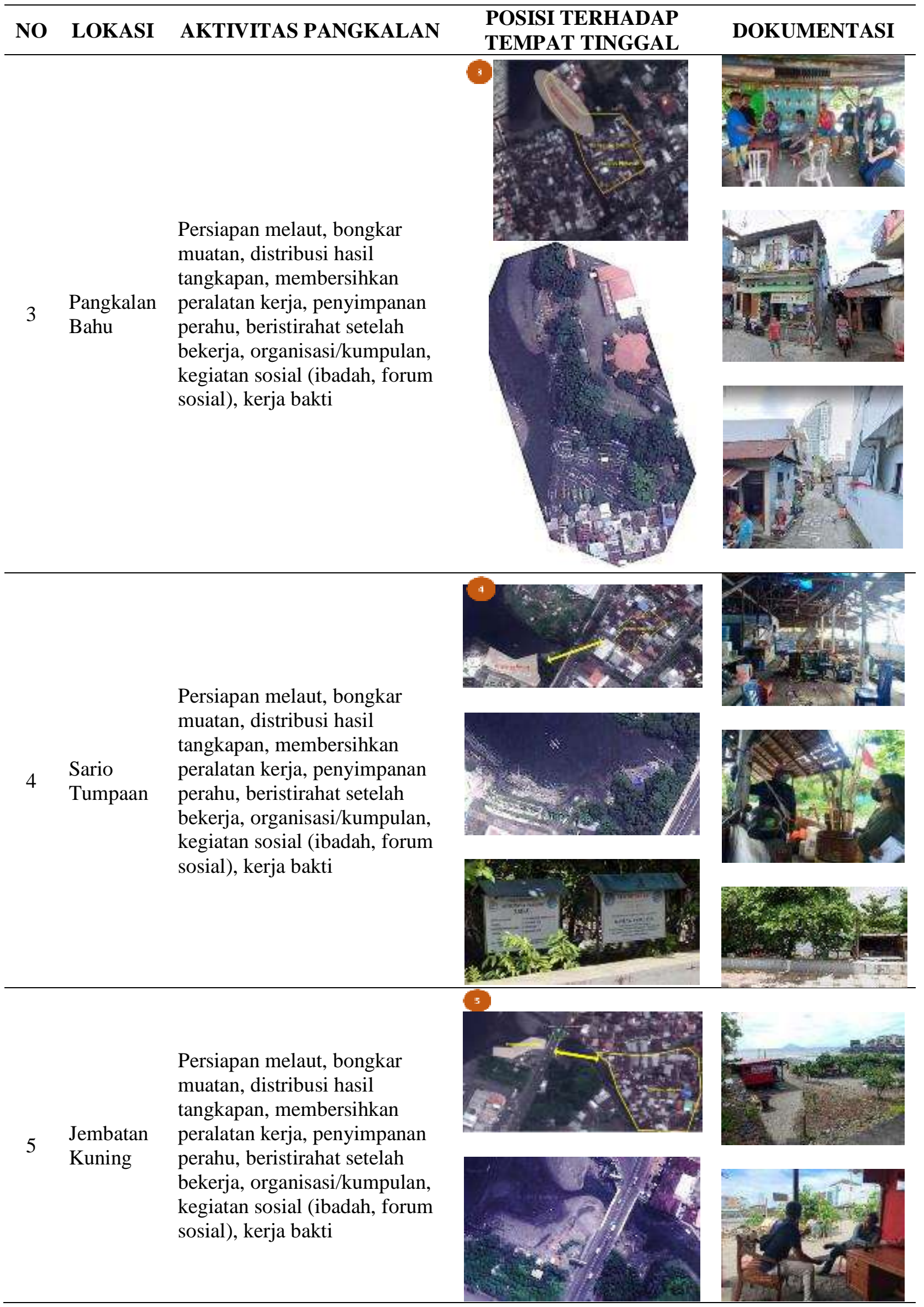

Edukatif : Jurnal Ilmu Pendidikan Vol 4 No 1 Tahun 2022 p-ISSN 2656-8063 e-ISSN 2656-8071 
419 Pendekatan Ekokultural pada Model Rancangan Pangkalan Perahu Tanggap Bencana di Kawasan Pesisir Kota Manado - Reny Syafrini, Sangkertadi, Rachmat Prijadi, Valeria Theresia Woy

DOI: https://doi.org/10.31004/edukatif.v4i1.1850

\begin{tabular}{lllll}
\hline NO LOKASI AKTIVITAS PANGKALAN & $\begin{array}{l}\text { POSISI TERHADAP } \\
\text { TEMPAT TINGGAL }\end{array}$ & DOKUMENTASI \\
\hline
\end{tabular}
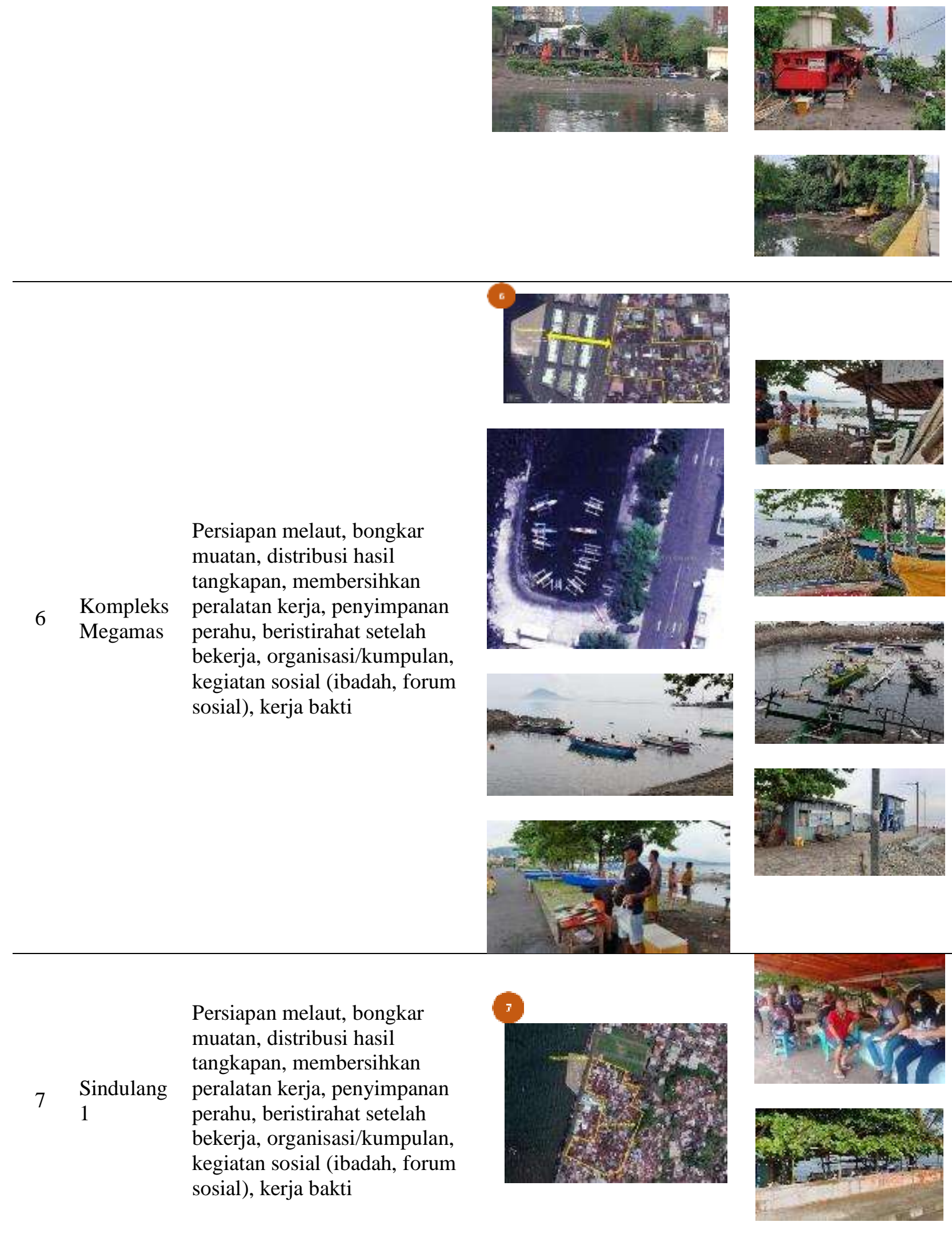
420 Pendekatan Ekokultural pada Model Rancangan Pangkalan Perahu Tanggap Bencana di Kawasan Pesisir Kota Manado - Reny Syafrini, Sangkertadi, Rachmat Prijadi, Valeria Theresia Woy

DOI: https://doi.org/10.31004/edukatif.v4i1.1850

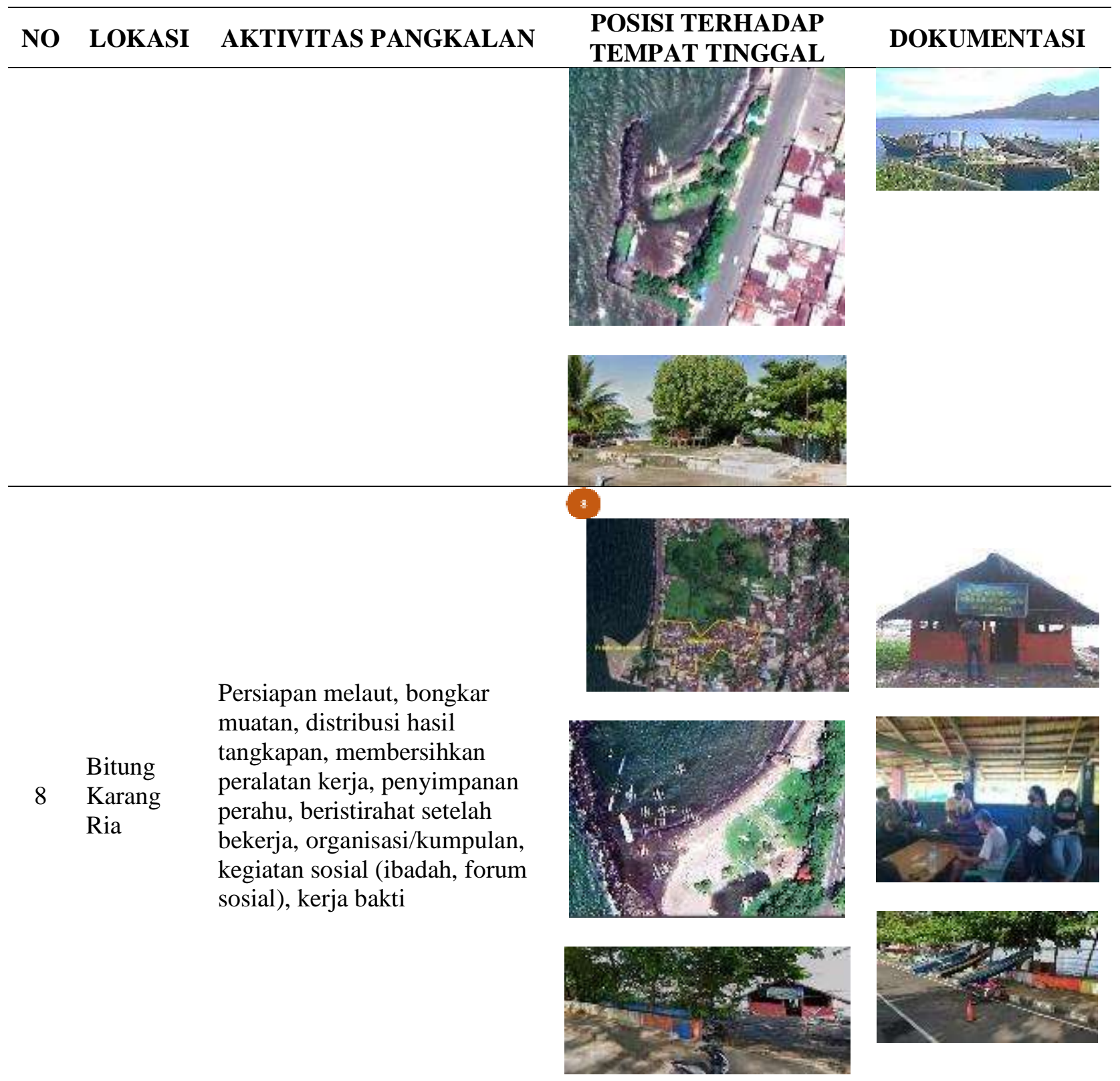

\begin{aligned} & \hline \multirow{3}{*}{ Maasing } $\begin{array}{l}\text { Persiapan melaut, bongkar } \\ \text { muatan, distribusi hasil } \\ \text { tangkapan, } \\ \text { membersihkan peralatan kerja, } \\ \text { penyimpanan perahu } \\ \text { Beristirahat setelah bekerja } \\ \text { Organisasi/kumpulan } \\ \text { Kegiatan sosial (Ibadah, } \\ \text { forum sosial) kerjabakti }\end{array} \\ &\end{aligned}$




\begin{tabular}{lccc}
\hline NO LOKASI & AKTIVITAS PANGKALAN & $\begin{array}{l}\text { POSISI TERHADAP } \\
\text { TEMPAT TINGGAL }\end{array}$ & DOKUMENTASI \\
\hline & & &
\end{tabular}

\section{Adaptasi Budaya di Lingkungan Urban}

Faktor sosial budaya merupakan salah satu hal yang paling penting dalam proses lahirnya bentuk arsitektur. Budaya menentukan cara hidup, kebiasaan dan tingkah laku tiap individu dan cara hidup setiap kelompok masyarakat menentukan bentukan arsitektur maupun pola penataan ruang arsitektur dalam suatu daerah atau kelompok masyarakat.

Pemahaman budaya yakni cara berkehidupan yang melibatkan tiga elemen penting yaitu nilai yang dianut, norma yang dipatuhi dan obyek material yang digunakan masyarakat dalam menjalankan kehidupan sehari-hari. Cara berkehidupan ini berubah sesuai dengan perkembangan zaman dan perubahan tempat dimana mereka tinggal.

Mapalose merupakan kegiatan tolong menolong dalam masyarakat adat Sangihe pada kegiatan mengerjakan ladang, membuat rumah, menangkap ikan dan lain-lain. Kegiatan ini merepresentasikan nilai yang masih dianut masyarakat ketika tinggal di kawasan urban seperti Kota Manado. Komunitas nelayan urban yang menjadi pokok kajian, telah lama beradaptasi dan secara turun temurun telah mewariskan budaya melaut dalam diaspora nya. Bentuk bentuk adaptasi dalam kehidupan urban yang dijalani tercermin dalam ruang ruang di pesisir kota yang dibentuk secara bersama sama dan membentuk sebuah pola ruang kehidupan yang terdiri dari tiga unsur pokok: hunian, pangkalan perahu, dan pasar. Ketiga unsur ini menjadi ruang budaya yang baru.

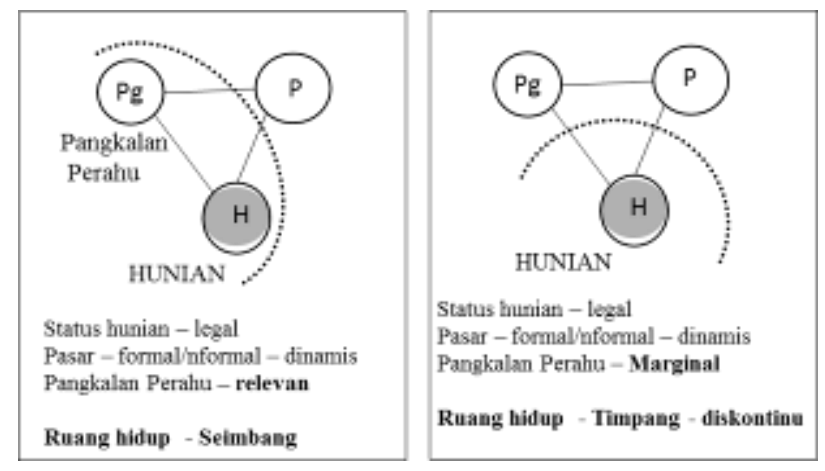

\section{Gambar 4: Model Kampung Nelayan Yang Beradaptasi Dalam Lingkungan Pesisir Urban}

Hasil survei menunjukkan bahwa sebagian besar nelayan bermukim di persisir Kota Manado berlatar belakang etnis Sanger yang berdiaspora ke berbagai tempat di luar tempat asal mereka, yang memiliki ketrampilan mencari ikan yang diperoleh secara turun temurun. Disamping etnis Sanger, juga terdapat masyarakat berlatar belakang budaya asal Gorontalo, yang umumnya hadir di kota sebagai pedagang hasil bumi. Khusus di Sindulang 1, banyak nelayan berlatar etnis Borgo, yakni masyarakat keturunan Portugis yang sudah berbaur dengan masyarakat etnis lokal.

\section{Adaptasi Budaya di Lingkungan Urban}

Pengetahuan tentang cara menangkap ikan dan pekerjaan utama dilaut umumnya diperoleh secara turun temurun. Khusus nelayan asal Sanger, di daerah asalnya terbiasa melakukan mata pencaharian di darat berupa aktivitas di bidang pertanian, yang dilakukan ketika musim angin barat dan laut menjadi tidak bersahabat. Diaspora ke pesisir urban Kota Manado merubah aktivitas di darat terutama ketika musim angin barat. 
Perubahan cara berkehidupan di perkotaan umumnya mengganti pekerjaan di darat dalam bidang jasa informal sebagai tukang, kegiatan jasa angkutan dan sebagainya menjadi pilihan atau altenatif lain. Pengetahuan masyarakat tentang berbagai hal yang berkaitan dengan mata pencaharian sebagai nelayan mempengaruhi perilaku mereka dalam melakukan aktivitasnya. Pedoman nelayan dalam melaut adalah: Musim, Peredaran Bulan, teknologi penangkapan ikan, dan lain sebagainya.

Pola mencari ikan pada jam 4.00-8.00 biasanya masyarakat berangkat berkelompok 2-3 orang. Dalam menjalani aktivitasnya para nelayan biasanya berlayar menyusuri pantai terutama di daerah teluk, karena menurut pengalaman mereka pada jarak antara 10 sampai 30 kilo meter dari pantai terdapat kawanan ikan sampai ribuan jumlahnya. Dan pada musim tertentu ikan-ikan tersebut akan mengikuti arus lebih dekat ke pantai atau ke teluk mencari air yang tenang untuk bertelur.

Para nelayan biasanya turun ke laut pada pukul empat pagi dan kembali pukul tujuh malam dengan membawa hasil tangkapan yang diperoleh semalaman di laut. Peralatan yang paling penting yang harus disiapkan oleh nelayan adalah kotak penampungan ikan. Kotak yang dirancang khusus dari gabus atau stereofoam dilengkapi dengan balok-balok es agar ikan yang diperoleh tetap segar untuk dijual pada besok pagi. Dalam melaksanakan pekerjaan para nelayan tidak melaut sendiri, tetapi biasanya dalam satu perahu ada dua sampai tiga orang atau empat sampai enam orang, tergantung ukuran atau jenis perahu. Untuk perahu londe biasanya dinahkodai oleh dua atau tiga orang sedangkan perahu pelang dengan ukuran 6 sampai 8 meter dan lebar 1 meter dinahkodai oleh empat sampai enam orang dengan menyusuri daerah operasi 5 sampai 7 mil.

Jenis-jenis perahu yang digunakan oleh nelayan skala kecil umumnya adalah perahu pambut, pelang, pamo, londe. Perahu yang berukuran kecil seperti pelang dan londe bisa menggunakan mesin tempel (Katingting) juga bisa didayung. mesin katinting lebih disukai karena tidak boros dalam penggunaan bahan bakar. Dengan kata lain menggunakan mesin katinting dapat menghemat bahan bakar, walau diakui daerah operasional perahu bermesin katinting hanya terbatas pada daerah pantai dan kepulauan atau jarak 5 sampai 8 mil.

Peralatan utama nelayan yang digunakan untuk mencari ikan adalah perahu. Perahu-perahu disebut diawaki oleh 2 sampai 10 orang tergantung ukuran perahu dan jenis mesin tempel yang digunakan, demikian juga jarak operasional perahu tergantung dari jenis mesin yang digunakan. Nelayan tradisional yang tergolong nelayan kecil ini tetapi rutin melaut setiap hari dengan mengandalkan perahu. Perahu nelayan yang digunakan terdiri dari beberapa jenis dan bentuk perahu yang digunakan erat kaitannya dengan budaya masyarakat suatu kelompok nelayan. Seperti contoh perahu londe dan perahu pelang yang menjadi perahu yang umumnya dipakai oleh masyarakat suku Sangihe sementara perahu model pelang kecil sering digunakan oleh masyarakat suku Bantik.
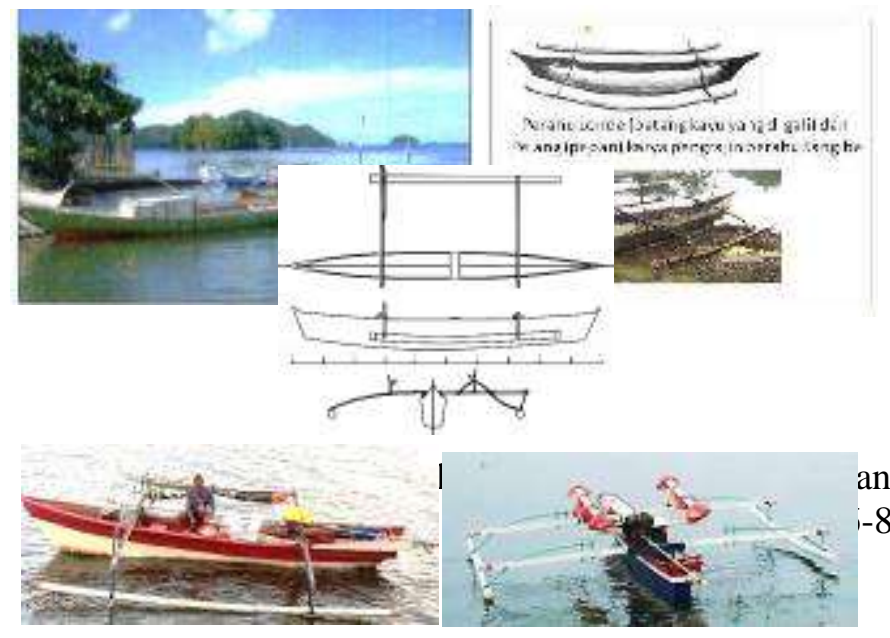


\section{Gambar 5: Perahu Pelang Kecil / Bercadik Khas Sulawesi Utara}

Selain bentuk perahu, terdapat juga beberapa jenis perahu yang digunakan nelayan kawasan pesisir Kota Manado berdasarkan mesin penggeraknya yang dapat dilihat pada tabel 3.

Tabel 3. Jenis Dan Jumlah Perahu Perikanan Di Perairan Kota Manado

\begin{tabular}{lc}
\hline \multicolumn{1}{c}{ Jenis Perahu } & Jumlah \\
\hline Katinting & 322 \\
\hline Perahu pelang/motor tempel & 143 \\
\hline Kapal ukuran 20-30 GT & 54 \\
\hline Kapal ukuran 30-50 GT & 2 \\
\hline Perahu tanpa motor & 835 \\
\hline Jumlah & 1356 \\
\hline
\end{tabular}

Selain perahu sebagai peralatan kerja utama para nelayan, ada beberapa peralatan kerja nelayan lainnya yang juga sangat penting untuk mendukung nelayan dalam mencari ikan diantaranya adalah jaring atau soma. Soma adalah jenis jaring yang digunakan untuk menjaring ikan arus, seperti: ikan tude, malaugis, deho, cakalang, sardin, lolosi dan lain-lain. Disebut ikan arus karena jenis-jenis ikan tersebut selalu mengikuti arus sehingga penangkap ikan menggunakan soma dilakukan pada saat ams air dalam keadaan tenang. Penggunaan jaring ini pada waktu malam dengan menggunakan lampu petromaks.

Penggunaan jaring hanya jika ada kepentingan atau keperluan bersama dalam kampung dengan menggunakan dua perahu dan perlengkapan dan tangkapan yang lebih banyak.

Sibu-sibu adalah sejenis jaring yang berukuran kecil yang dirajut dari benang nil on dengan ukuran gaiis tengah 30 sampai $100 \mathrm{~cm}$. Sibusibu dibuat dari rotan atau besi yang dibuat melengkung atau bulat dan diberi tangkai dengan ukuran 1 sampai 2 meter atau adajuga yang tidak memakai tangkai. Sibu-sibu digunakan untuk menciduk ikan yang kecil-kecil ataujuga agak besar, dan yang paling banyak digunakan untuk menciduk ikan putih atau ikan teri.

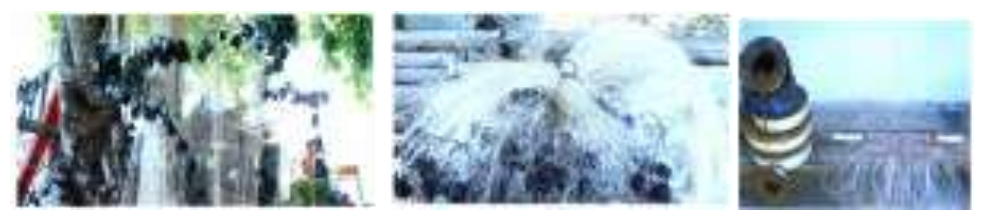

Gambar 6: Distribusi Hasil Tangkapan Nelayan Sario Dan Bahu Yang Langsung Dijual Di Pangkalan Atau Dibawa Ke Pasar Bahu

Menangkap ikan dengan pancing (bawae) biasa disebut mangail, saat ini untuk memancing para nelayan menggunakan umpan dari kain yang berwarna cerah seperti putih, merah muda atau pun hijau, juga menggunakan umpan ikan sesuai dengan jenis ikan yang akan dipancing. Jika memancing ikan yang besar digunakan ikan yang agak kecil dan jika memancing suntung atau cumi digunakan umpan yang berbentuk cumi.

Selain itu digunakan juga jenis panah, tombak sebagai peralatan menangkap ikan yang terbuat dari besi. Alat ini biasanya digunakan oleh nelayan untuk menangkap ikan sambil menyelam, sehingga digunakan diperairan dangkal atau di napo ikan yang diperoleh adalah ikan-ikan karang atau ikan batu. 
Setelah mendapatkan hasil tangkapan para nelayan langsung mendistribusikan hasil tangkapan dengan beberapa cara tergantung kesepakatan masing-masing organisasi kelompok nelayan.

Hasil tangkapan dibagi sesuai anggota yang ikut menangkap ikan. Jika berlebih di serahkan ke penjual di pasar. Ikan yang mereka peroleh biasanya didistribusikan secara langsung atau pun tidak langsung kepada konsumen. Ikan yang didistribusikan langsung dari nelayan kepada konsumen biasanya jenis ikan yang kecilkecil atau jenis ikan yang tidak tahan lama yang dijual langsung oleh nelayan di pasar yang ada di Lapango pusat kecamatan. Sedangkan ikan yang besar atau yang harganya mahal biasanya dijual ke Tahuna secara tidak langsung atau penjualan yang dilakukan oleh nelayan dengan pelanggan atau tibo sebagai perantara yang nantinya akan menjual ke pasar atau kerumah-rumah makan Bagi nelayan yang melakukan pekerjaan berkelompok mereka memiliki sistem upah dengan cara pembagian hasil. Setiap nelayan yang terlibat mendapat bagian tertentu dari hasil yang diperoleh sesuai kesepakatan yang mereka atur bersama. Cara pembagian hasil tersebut adalah dari hasil yang mereka peroleh, ada sebagian yang disisihkan untuk konsumsi sendiri atau keluarga dan lainnya dijual ke konsumen.

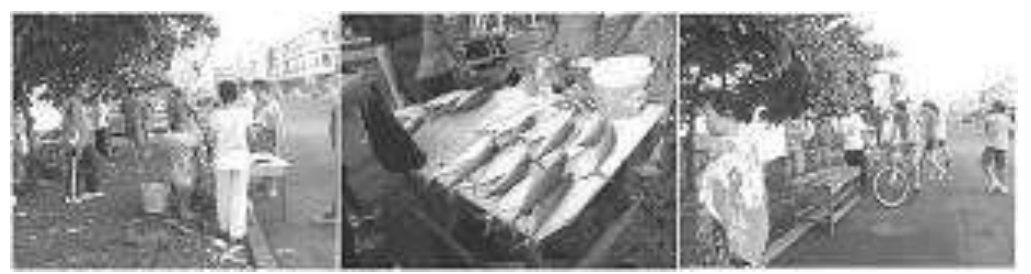

\section{Gambar 7: Distribusi Hasil Tangkapan Nelayan Sario Dan Bahu Yang Langsung Dijual Di Pangkalan Atau Dibawa Ke Pasar Bahu}

Uang yang diperoleh dari hasil penjualan ikan atau hasil kotor yang diperoleh disisihkan dulu untuk biaya pemeliharaan perahu dan peralatan lainnya serta pengeluaran yang terjadi disaat melaut dan sisanya dibagi bersama, sesuai kesepakatan pemilik perahu mendapatkan bagian lebih besar. Dalam menjual ikan hasil tangkapan pada urnurnnya nelayan tidak menernui kesulitan karena rnereka sudah rnernpunyai pelanggan tetap. Transaksi antara nelayan dengan pernbeli dilakukan dilokasi pendaratan perahu yang ada di pasar Tahuna pada pukul 05.00 sarnpai 07.00. Dalam pengamatan dilapangan penjualan ikan dilakukan dengan cara, jenis ikan kecil ditakar dalam ember sedangkan jenis ikan besar dihitung perekor.

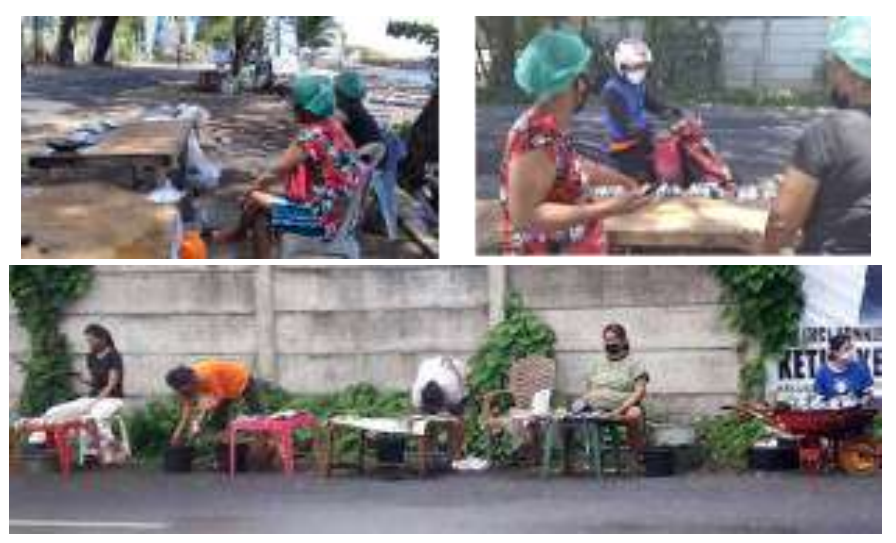

\section{Gambar 8: Penjualan Hasil Tangkapan Di Pinggir Jalan Akibat Pandemi}

Di saat musim hujan, terutama jika disertai angin barat, nelayan umumnya tidak mengambil resiko untuk melaut karena ancaman bencana alam. Sebagian besar nelayan mencoba bertahan hidup dengan melakukan pekerjaan sampingan sesuai dengan kemampuan. Mengingat terbatasnya ketrampilan yang dimiliki, umumnya nelayan bekerja lepas di bidang jasa angkutan, atau sekedar membantu keluarga dengan 
berdagang makanan. Bagi yang memiliki ketrampilan membuat perahu, masa tidak melaut dimanfaatkan untuk memperbaiki perahu atau menerima pesanan pembuatan perahu dari luar wilayah. Diakui oleh nelayan bahwa sejak adanya reklamasi di pesisir kota, daerah tangkapan nelayan semakin menjauh dari garis pantai, dan hasil tangkapan juga menjadi lebih sedikit sertta resiko kerusakan perahu juga meningkat. Namun karena kemampuan dan keterampilan lain yang sangat terbatas nelayan tidak memiliki pilihan lain untuk bekerja kecuali melaut.

\section{Kondisi Ekoregion dan Bencana Gelombang Pasang}

Karakteristik ekologi pantai manado mempengaruhi pola aktivitas kehidupan nelayan yang menggantungkan hidup dari mencari ikan di perairan pantai kota. Menurut Peta Indeks Ancaman Bencana Gelombang Pasang/Abrasi (Kurniawan et al., 2011), Kota Manado termasuk dalam tingkat ancaman "sedang" untuk gelombang pasang/abrasi. Frekuensi badai laut yang tinggi berdampak bencana di kawasan pantai yang dapat merusak permukiman dan properti nelayan.

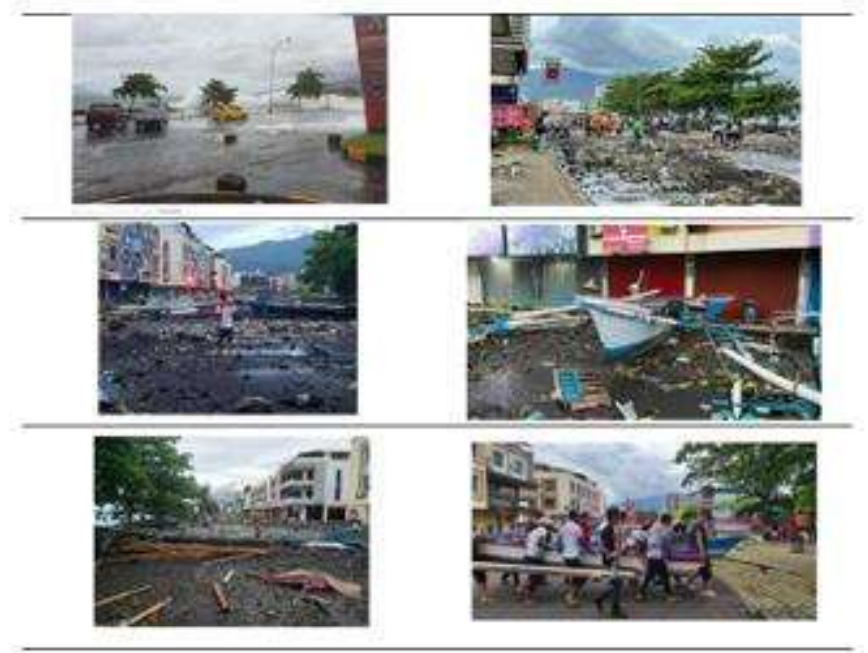

\section{Gambar 9: Dampak Gelombang Pasang Dan Angin Kencang Di Kota Manado Tahun 2021}

Fenomena cuaca alamiah yang biasa terjadi terutama pada saat puncak musim hujan. Ancaman bahaya terjadi ketika fase pasang air laut berbarengan dengan gelombang tinggi dan angin kencang. Oleh sebab itu, pemukim di pesisir pantai harus lebih waspada terhadap gelombang tinggi, terutama jika bangunan terbuat dari bahan yang tidak permanen. Energi gelombang yang datang cukup tinggi dan mampu menghantam rumah bahkan menggerus rumah.

Gelombang pasang adalah gelombang air laut yang melebihi batas normal, dan dapat menimbulkan bahaya di laut maupun di darat terutama daerah pinggir pantai. Umumnya gelombang pasang terjadi karena adanya angin kencang/puting beliung, perubahan cuaca yang sangat cepat, dan karena ada pengaruh dari gravitasi bulan maupun matahari. Kecepatan gelombang pasang sekitar 10-100 Km/ jam. Gelombang pasang di laut akan menyebabkan tersapunya daerah pinggir pantai yang disebut dengan abrasi (Hairami, 2019).

Fenomena ini bisa berdampak di mana saja yang lebih luas, tergantung bagaimana pelindung pantainya, (break water), atau sea wall. Dampak bencana gelombang pasang tidak dapat di remehkan. Kerusakan sarana dan prasarana, termasuk perumahan, infrastruktur transportasi, pelabuhan, merupakan dampak fisik yang langsung dirasakan oleh masyarakat sekitar pesisir. Dampak ini memerlukan antisipasi dalam pemeliharaan dan pembuatan infrastruktur di pesisir. Salah satu cara yang dilakukan adalah membangun bangunan pemecah ombak untuk mengurangi energi gelombang yang cukup besar yang datang di pesisir.

Laporan dari BMKG menjelaskan tentang naiknya air laut di pesisir Kota Manado pada tanggal 17 Januari 2021 menyebutkan luapan air laut tersebut bukan tsunami melainkan merupakan salah satu kejadian 
cuaca ekstrem yang terjadi di wilayah Indonesia. Luapan air laut ke pesisir pantai dipengaruhi beberapa faktor, salah satunya, angin kencang dengan kecepatan maksimum 25 knot yang berdampak pada peningkatan tinggi gelombang di Laut Sulawesi, tepatnya di perairan utara Sulawesi Utara, perairan Kepulauan SangiheKepulauan Talaud, dan Laut Maluku bagian utara. Ketinggian gelombangnya mencapai 2,5-4,0 meter.

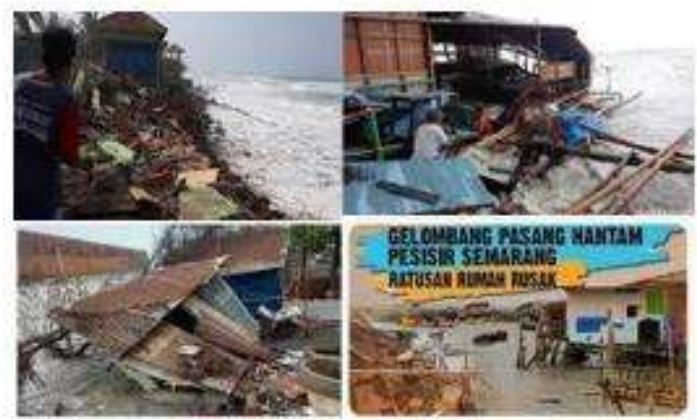

\section{Gambar 10: Gelombang Pasang Yang Melanda Sejumlah Kota Pesisir Di Indonesia Yang Menyebabkan Kerugian Materil Bagi Masyarakat Yang Bermukim Di Kawasan Pesisir}

Terdapat pengaruh kondisi pasang air laut maksimum di wilayah Manado yang menunjukkan peningkatan pasang maksimum harian. Tingginya mencapai 170-190 sentimeter dari rata-rata tinggi muka air laut. Berdasarkan analisis gelombang, diketahui arahnya tegak lurus dengan garis pantai, sehingga dapat memicu naiknya air ke wilayah pesisir. Gabungan gelombang tinggi dengan angin kencang di pesisir serta fase pasang air laut maksimum itu yang menyebabkan terjadi kenaikan air laut sehingga mengakibatkan banjir dan merusak properti nelayan terutama perahu yang di simpan pada pangkalan perahu.

\section{Konsep Eko Kultural Pangkalan Perahu Masyarakat Nelayan}

Ekologi kultural adalah studi tentang adaptasi manusia untuk lingkungan sosial dan fisik nya. Sebuah cara pandang memahami persoalan lingkungan hidup dalam perspektif budaya, atau sebaliknya bagaimana memahami kebudayaan dalam perspektif lingkungan hidup. Bagaimana cara manusia memanipulasi dan membentuk ekosistemnya sendiri. Dalam penelitian ini, terungkap bahwa komunitas nelayan kota Manado membentuk ekosistem bagi kelompok nya dalam menjalankan kehidupan harian dengan memanfaatkan ruang pantai sebagai basis utama ruang bekerja sehari hari. Mereka memproduksi ruang melalui beragam aktivitas seperti diuraikan di bab sebelumnya.

Logika eko-kultural, Guy dan Palmer menarik inspirasi dari pertanggungjawaban fenomenologi lingkungan dan kebangkitan kembali konsep Heidegger tentang penghunian dengan menekankan penghunian kembali atau belajar kembali tentang rasa ruang. Rasa unik identitas ini berkembang secara subyektif dari dalam alam dan ada kepedulian terhadap kesinambungan makna antara tradisi dan individu (Guy \& Farmer, 2001). Pendekatan ini menekankan pada desentralisasi dan mempertimbangkan karakteristik wilayah (region) dan karakteristik hayati wilayah (bio region).

Logika eko kultural dalam arsitektur berkelanjutan menekankan reorientasi fundamental nilai nilai yang mengedepankan aspek lingkungan fisik dan budaya masyarakat setempat dengan melestarikan keragaman budaya yang ada, yang telah berlangsung secara turun temurun. Hal ini merupakan tanggungjawab etis untuk melawan universalitas budaya modern yang mengglobal belakangan ini. Upaya melestarikan budaya lokal tersebut antara lain dengan memperhatikan bentuk kegiatan dan pola aktivitas harian masyarakat dalam menggunakan ruang sebagai bagian dari ruang hidup dan ruang berkehidupan.

Bencana gelombang pasang yang kerap melanda kawasan pesisi Kota Manado mendorong masyarakat yang bermukim di kawasan pesisir khususnya para nelayan membuat ruang baru sebagai bentuk adaptasi terhadap kondisi iklom lokal pesisir pantai. 


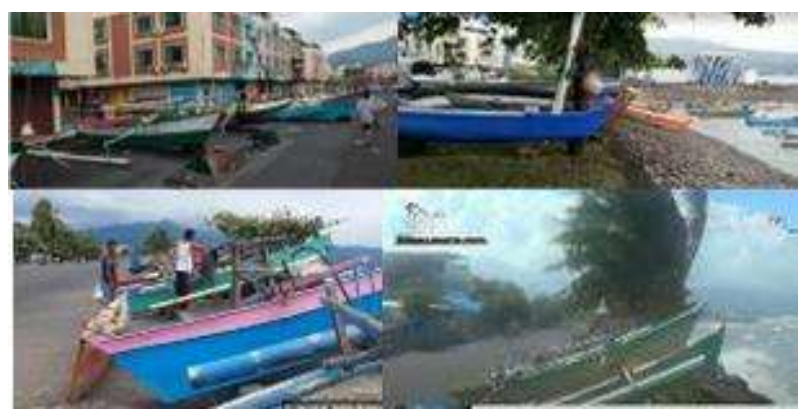

\section{Gambar 11: Perahu-Perahu Yang Diparkir Pada Ruang Terdekat Untuk Mengindari Bencana}

Rancangan arsitektur pangkalan perahu nelayan pesisir urban adalah hasil sintesis dari tema rancangan yang berbasis ketahanan terhadap bencana, khususnya bencana gelombang pasang. Adapun pendekatan terhadap rancangan ini mengacu pada konsep Mitigasi berupa perbaikan model ruang tambatan yang adaptif terhadap budaya dan kondisi ekologi lokal. Konsep rancangan yang adaptif ini mengakomodasikan serangkaian kegiatan yang dilakukan oleh nelayan dalam beraktivitas baik sebelum maupun sesudah melakukan kegiatan penangkapan ikan. Hal ini dituangkan dalam konsep program ruang yang mewadahi 3 kelompok aktivitas utama, yaitu:

1. Sebelum melaut: persiapan peralatan kerja, persiapan perahu

2.Sesudah melaut: kegiatan bongkar muat, distribusi hasil tangkapan, penyimpanan peralatan kerja dan pemeliharaan peralatan

3. Kegiatan sosial: perkumpulan/organisasi, ibadah dan pendidikan khusus

4. Parkir/sandaran perahu yang tanggap bencana

\section{Konsep Permodelan Arsitektur Pangkalan Perahu Tanggap Bencana}

\section{a. Model Pangkalan Perahu}

Logika ekokultural menekankan pelestarian berbagai archetipe budaya yang dibangun yang sudah ada, digabungkan dengan kepedulian terhadap kesinambungan budaya yang diekspresikan melalui transformasi dan penggunaan kembali teknik konstruksi tradisional, tipologi bangunan, dan pola pemukiman, masingmasing dengan sejarah local evolusi dan penggunaan. Penekanan pada kekhasan tempat, penggunaan bahanbahan lokal, dan respons formal yang tepat terhadap kondisi iklim dan iklim. Berdasarkan pola aktivitas harian masyarakat nelayan di pesisir kota Manado, serta hasil pengamatan lapangan di beberapa spot ruang pangkalan perahu, maka diusulkan model pangkalan perahu yang tanggap bencana, khususnya bencana gelombang pasang.

Konsep rancangan model pangkalan perahu dengan dua pendekatan yakni fungsi dan ketahanan terhadap bencana. Aspek fungsional pangkalan, selain sebagai ruang persiapan melaut, bongkar muat, dan distribusi hasil tangkapan, pangkalan juga berfungsi sebagai ruang sosial bagi komunitas nelayan tradisional. Beberapa kegiatan yang sering dilakukan di tempat ini adalah berisitrahat sambil membersihkan peralatan kerja, melakukan pertemuan, ibadah, dan juga kegiatan organisasi / sekretariat perkumpulan. Zamzami dan Hendrawati menggarisbawahi kearifan budaya lokal masyarakat maritim menjadi bagian penting dalam memitigasi bencana alam yang mungkin terjadi di wilayah pesisir Sumatera Barat (Zamzami \& Hendrawati, 2014). Hasil penelitian terdahulu menunjukkan bahwa pada beberapa kampung pesisir yang tersebar di sepanjang pesisir kota Manado aktivitas di pangkalan perahu umumnya difungsikan untuk pendaratan perahu, bongkar muatan hasil tangkapan, dan mendistribusikan hasil tangkapan (Syafriny et al., 2018). Pangkalan juga berfungsi sebagai ruang sosial tempat berkumpul dan melakukan pemeliharaan dan perawatan peralatan kerja lainnya. Secara spasial, pemanfaatan ruang di pangkalan perahu belum menunjukkan formasi lingkungan yang 
428 Pendekatan Ekokultural pada Model Rancangan Pangkalan Perahu Tanggap Bencana di Kawasan Pesisir Kota Manado - Reny Syafrini, Sangkertadi, Rachmat Prijadi, Valeria Theresia Woy

DOI: https://doi.org/10.31004/edukatif.v4i1.1850

layak dan persyaratan teknis yang mampu melindungi permukiman dari berbagai ancaman terhadap kebencanaan khususnya ketika badai musiman datang.

Hasil analisis dari beberapa ruang pangkalan perahu yang dibentuk oleh masyarakat pesisir, khususnya nelayan, telah menciptkan dua model rancangan pangkalan dengan karakteristik yang berbeda. Pertama, pangkalan perahu yang dibentuk di muara sungai memerlukan persyaratan yang berbeda dibandingkan dengan pangkalan perahu yang terletak bukan di muara sungai.

\begin{tabular}{ll} 
Tabel 4. Karakteristik Model Rancangan Pangkalan Perahu \\
\hline $\begin{array}{l}\text { Lokasi Muara Sungai/ } \\
\text { Estuaria }\end{array}$ & Jauh dari Muara Sungai \\
\hline $\begin{array}{l}\text { Pengaruh pasang surut dari } \\
\text { sungai dan laut }\end{array}$ & $\begin{array}{l}\text { Pengaruh pasang surut hanya } \\
\text { dari laut }\end{array}$ \\
\hline Sedimentasi sungai & Sedimentasi arus bawah laut
\end{tabular}

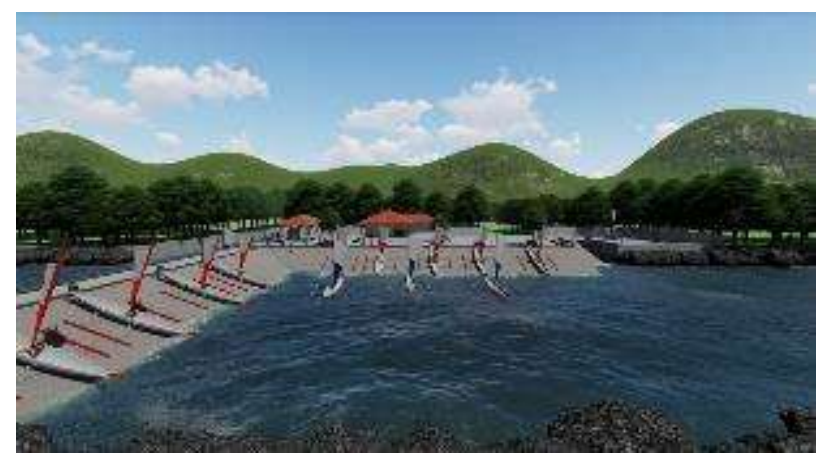

Gambar 12: Model Rancangan 1 - Pangkalan Di Muara Sungai

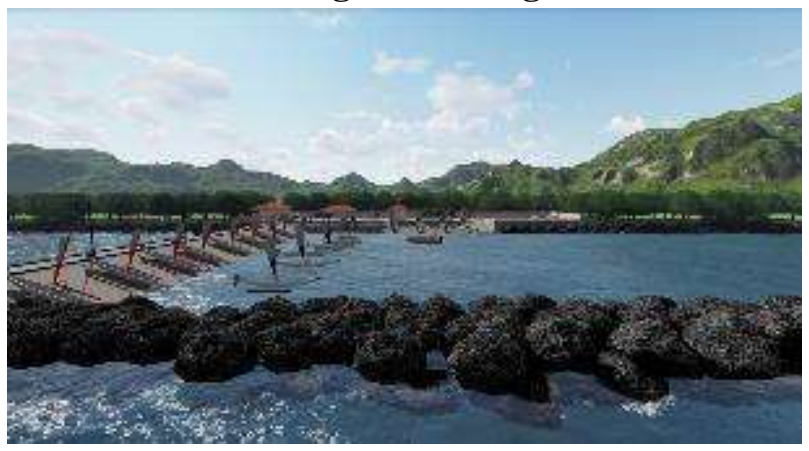

Gambar 13: Model Rancangan 2 - Pangkalan Perahu Di Luar Muara Sungai

b. Persyaratan Teknis Tambatan Perahu

Sebagai kelengkapan sistem pelayanan masyarakat khusus yakni: kemudahan aksesibilitas, tempat bongkar muat, pendistribusian hasil tangkapan, rekreasi, parkir antar moda. Untuk kebutuhan tersebut dibutuhkan dukungan data tentang kecepatan aliran sungai, kelandaian tepi sungai/laut, tinggi muka air pasang surut, kecepatan aliran air (sungai dan arus), kedalaman sungai/laut (maksimal $6 \mathrm{~m}$ ) tinggi gelombang laut, jenis tanah, dimensi perahu, jumlah pengguna tambatan perahu.

Jenis konstruksi tambatan perahu dapat dilihat pada tabel berikut.

Tabel 5. Karakteristik Model Rancangan Pangkalan 
429 Pendekatan Ekokultural pada Model Rancangan Pangkalan Perahu Tanggap Bencana di Kawasan Pesisir Kota Manado - Reny Syafrini, Sangkertadi, Rachmat Prijadi, Valeria Theresia Woy

DOI: https://doi.org/10.31004/edukatif.v4i1.1850

\begin{tabular}{llcl}
\hline No & Bentuk Tepi & $\begin{array}{l}\text { Perbedaan } \\
\text { Muka Air }\end{array}$ & Jenis Konstruksi \\
\hline 1 & Landai & $<2 \mathrm{~m}$ & $\begin{array}{l}\text { Tambatan dermaga } \\
\text { berlantai 1 }\end{array}$ \\
\hline 2 & Landai & $>2 \mathrm{~m}$ & $\begin{array}{l}\text { Tambatan dermaga } \\
\text { berlantai 2 }\end{array}$ \\
\hline 3 & Curam & $<2 \mathrm{~m}$ & $\begin{array}{l}\text { Tambatan dermaga } \\
\text { berlantai 1 }\end{array}$ \\
\hline 4 & Curam & $>2 \mathrm{~m}$ & $\begin{array}{l}\text { Tambatan dermaga } \\
\text { berlantai 2 }\end{array}$
\end{tabular}

Sumber: Petunjuk Praktis Pembangunan, Pengoperasian dan Pemeliharaan Tambatan Perahu, DJCK, Kementerian Pekerjaan Umum

Tabel 6. Data Teknis Ukuran Bahan dan Jarak Pemasangan Pada Pekerjaan Tambatan Perahu

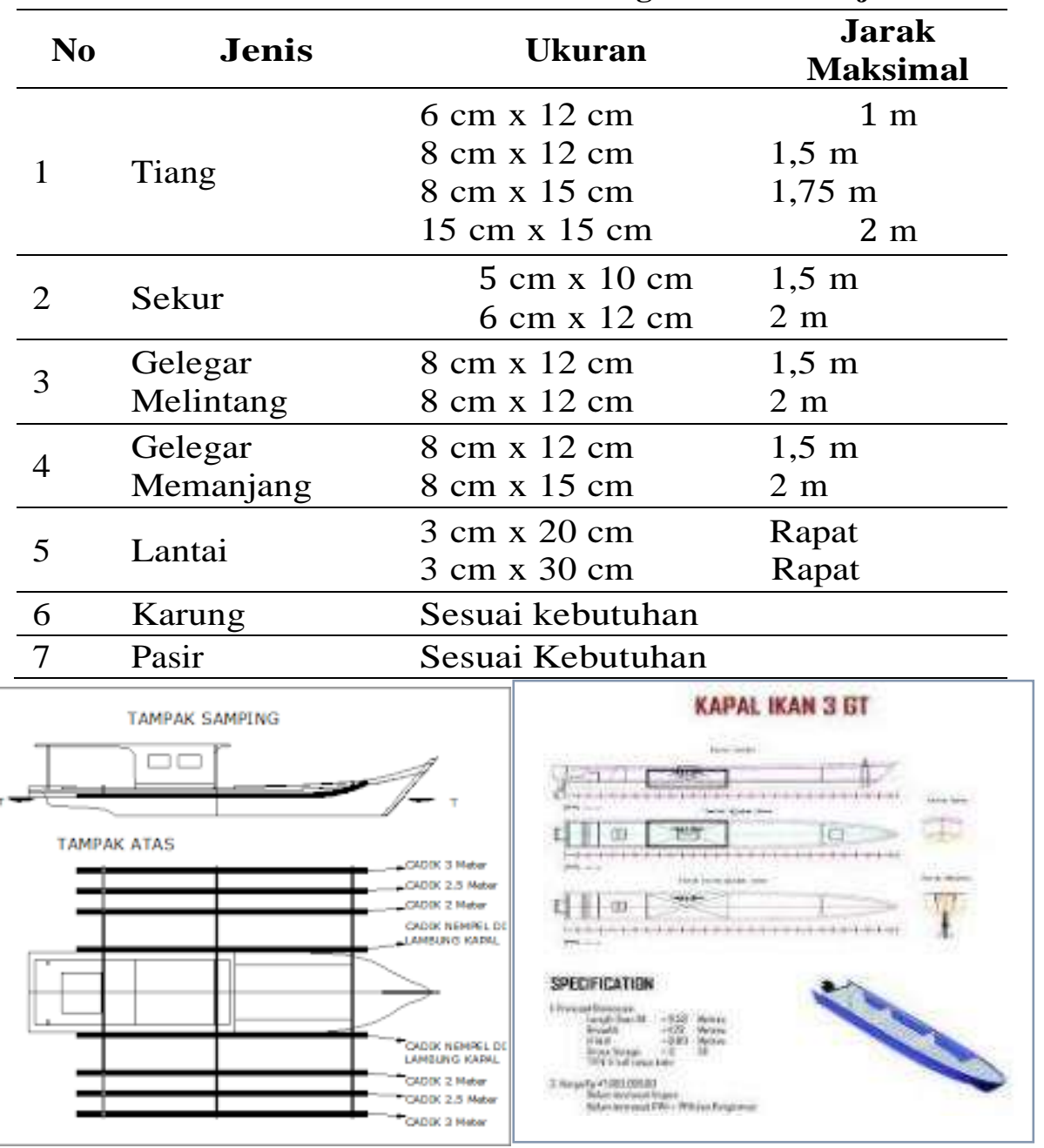

Gambar 14: Kapal Ikan 3 GT, Batas Kepemilikan Perahu Nelayan Tradisional

c. Kebutuhan Ruang

Konsep rancangan pangkalan perahu tanggap bencana memiliki beberapa ruang dalam yang dihubungkan oleh ruang luar. Ruang dalam terdiri dari ruang sekretariat, ruang sosial nelayan, gudang, MCK dan area distribusi ikan. Sementara ruang luar yang menjadi penghubung ruang dalam terdiri dari area 
430 Pendekatan Ekokultural pada Model Rancangan Pangkalan Perahu Tanggap Bencana di Kawasan Pesisir Kota Manado - Reny Syafrini, Sangkertadi, Rachmat Prijadi, Valeria Theresia Woy

DOI: https://doi.org/10.31004/edukatif.v4i1.1850

tambatan perahu, dermaga, ruang bongkar muat, ruang jemur jaring, ruang reparasi kapal dan ruang evakuasi kapal saat terjadi bencana.

Ruang-ruang tersebut dihadirkan untuk mewadahi kegiatan-kegiatan yang ada di pangkalan perahu, yaitu persiapan melaut, bongkar muat, distribusi hasil tangkapan dan kegiatan sosial komunitas nelayan. Ruang evakuasi kapal juga diadakan untuk merespon kearifan budaya lokal masyarakat maritim sehingga dibutuhkan mitigasi bencana alam berupa parkir/sandaran perahu yang tanggap bencana.

Alur kegiatan di pangkalan nelayan serta kebutuhan ruangnya diuraikan pada diagram berikut:

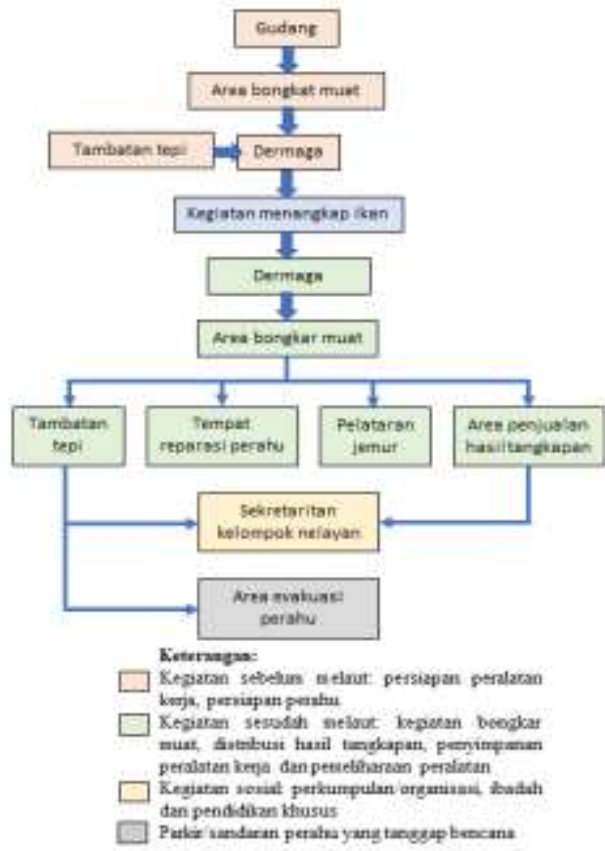

Gambar 15: Diagram Alur Kegiatan Dan Kebutuhan Ruang Di Pangkalan Perahu

d. Penataan Ruang Dalam dan Ruang Luar

Ruang luar ditata berdasarkan konsep program ruang yang mewadahi 4 aktivitas utama pada pangkalan perahu. Ruang bongkar muat berbatasan langsung dengan dermaga dan tambatan tepi karena kegiatan bongkar muat merupakan kegiatan pertama yang dilakukan nelayan saat sampai ke dermaga setelah menangkap ikan.
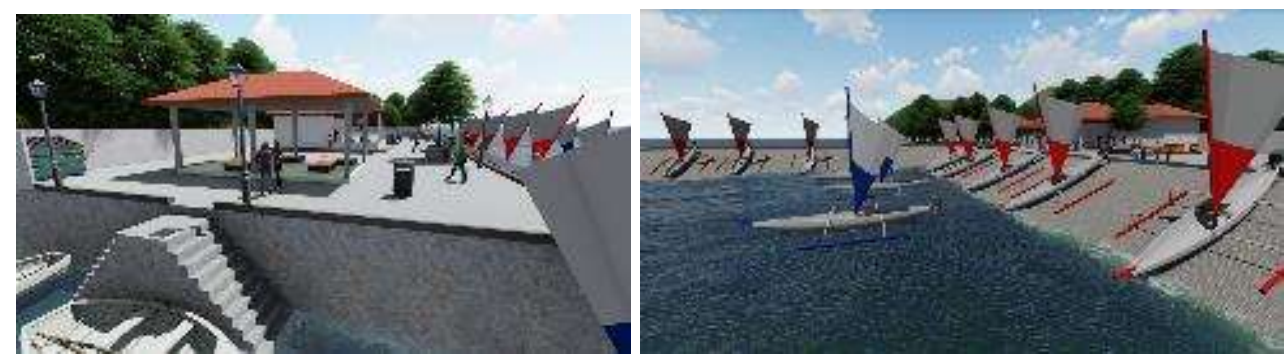

Gambar 16: Dermaga Dan Ruang Bongkar Muat, Serta Tambatan Tepi Model Rancangan 1 
431 Pendekatan Ekokultural pada Model Rancangan Pangkalan Perahu Tanggap Bencana di Kawasan Pesisir Kota Manado - Reny Syafrini, Sangkertadi, Rachmat Prijadi, Valeria Theresia Woy

DOI: https://doi.org/10.31004/edukatif.v4i1.1850

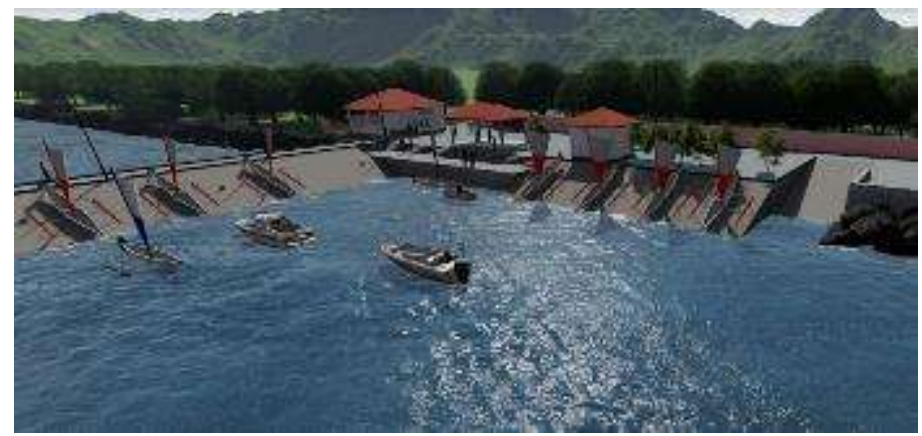

Gambar 17: Dermaga, Ruang Bongkar Muat, Serta Tambatan Tepi Model Rancangan 2

Sekretariat kelompok nelayan berbatasan langsung dengan ruang bongkar muat dan penjualan hasil tangkapan sehingga ketiga ruang ini membentuk zona publik yang sering diakses juga oleh masyarakat sekitar seperti pada gambar 18 .
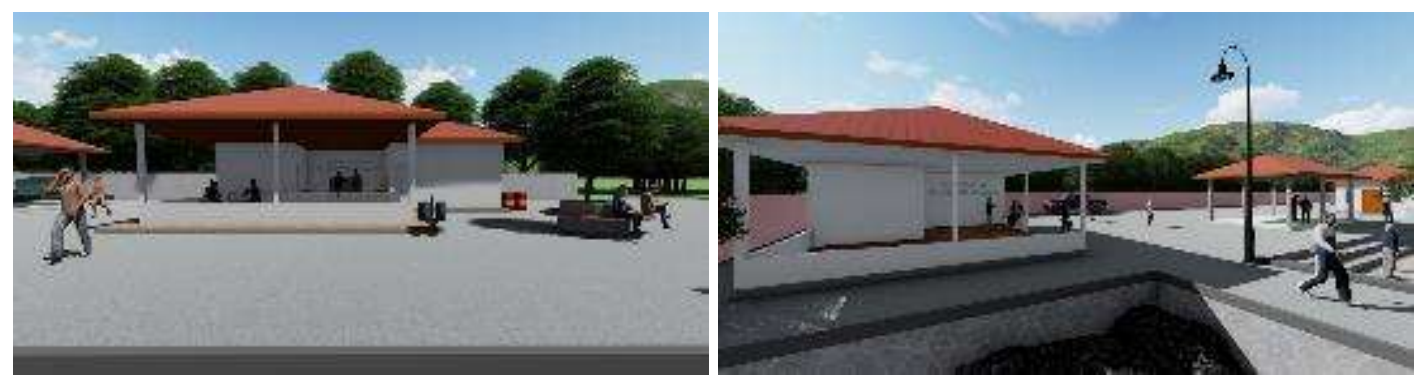

Gambar 18: Sekretariat Kelompok Nelayan Model Rancangan 1 (Kiri) Dan Model Rancangan 2 (Kanan)

Selain itu pelataran jemur jala, jalur evakuasi darurat, tambatan darurat dan tempat reparasi perahu terletak di area yang lebih jauh dari dermaga karena area ini lebih sering diakses oleh nelayan saja, sehingga merupakan zona semi publik. Zona publik dan semi publik dibatasi oleh pembatas ruang berupa vegetasi.
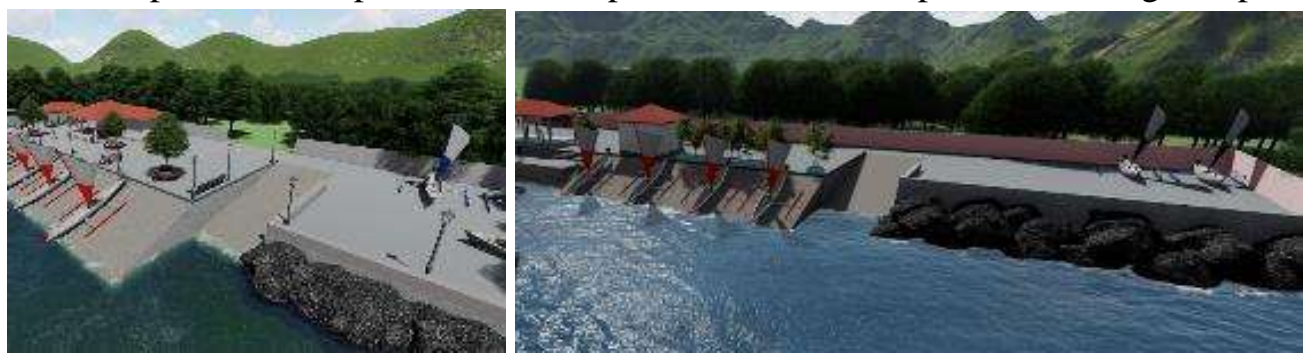

Gambar 19: Pelataran Jemur Jala, Jalur Evakuasi Perahu Dan Tambatan Darurat Perahu/Tempat Reparasi Perahu Model Rancangan 1 (Kiri) Dan Model Rancangan 2 (Kanan)

Ruang dalam terdiri dari ruang sekretariat, ruang sosial nelayan, gudang, MCK dan area distribusi ikan. Area distribusi ikan berbatasan langsung dengan ruang bongkar muat karena muatan ikan yang dibongkar akan langsung dibawa ke area distribusi tangkapan.

Pada Model Rancangan 1 gudang berada dalam 1 bangunan dengan kesekretariatan kelompok nelayan sedangkan pada Model Rancangan 2 gudang memiliki 1 massa sendiri. Poin penting dari letak gudang pada pangkalan perahu ini adalah posisinya yang selalu berbatasan langsung dengan pelataran jemur jala baik itu di Model Rancangan 1 maupun Model Rancangan 2. Ini disebabkan karena gudang merupakan tempat 
432 Pendekatan Ekokultural pada Model Rancangan Pangkalan Perahu Tanggap Bencana di Kawasan Pesisir Kota Manado - Reny Syafrini, Sangkertadi, Rachmat Prijadi, Valeria Theresia Woy

DOI: https://doi.org/10.31004/edukatif.v4i1.1850

penyimpanan peralatan nelayan termasuk jala, sehingga sesudah jala dijemur akan langsung disimpan di gudang.

Bangunan kesekretariatan kelompok nelayan ditata menurut pembagian zona publik, semi publik dan privat. Ruang sosial nelayan sebagai zona publik tidak memiliki dinding sebagai pembatas ruang, sedangkan ruang sekretariat dan MCK dibatasi oleh dinding masif yang membuat kedua ruang ini lebih tertutup.

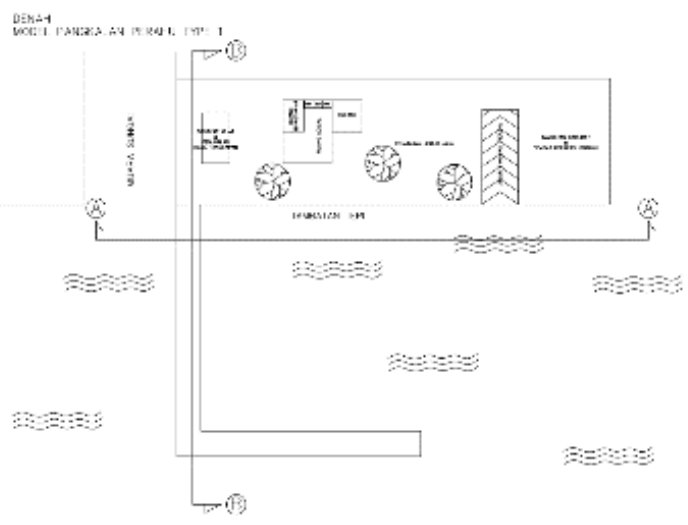

\section{Gambar 20: Denah Model Rancangan 1 Pangkalan Perahu}

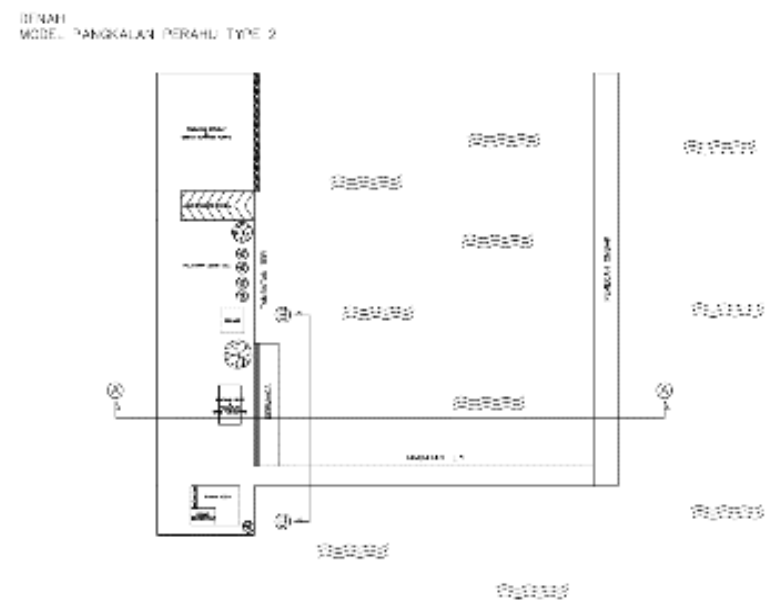

\section{Gambar 21: Denah Model Rancangan 2 Pangkalan Perahu}

e. Konsep Bentuk

Bentuk dari massa yang ada di pangkalan perahu mempunyai bentuk dasar kubus dan limas segi empat. Dalam membentuk massa yang ada kubus dan limas mengalami transformasi dimensional dan pengurangan, lalu digabungkan satu sama lain dalam transformasi aditif.

Bentuk yang dihasilkan dari transformasi massa tersebut adalah bentuk yang sering didapati pada bangunan lokal masyarakat maritim dan bangunan di daerah beriklim tropis. Bentuk bangunan seperti ini akrab dikenal di antara komunitas nelayan tradisional.
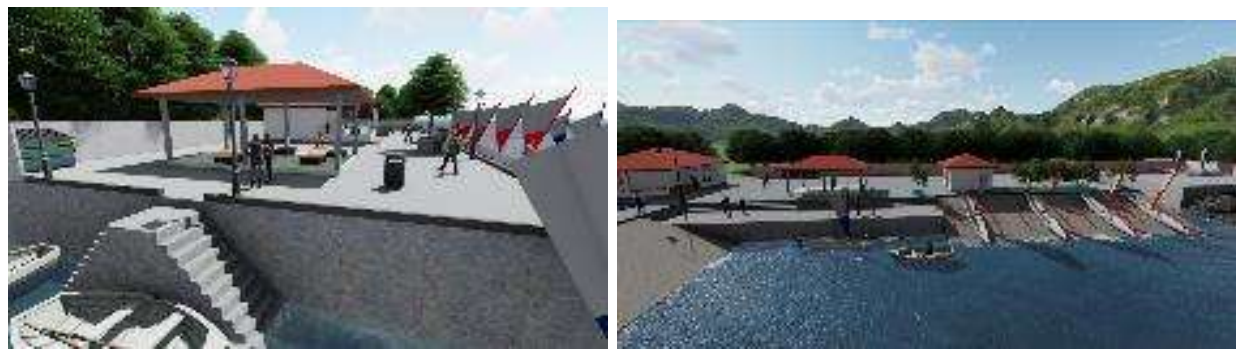

Gambar 22: Bangunan Di Pangkalan Perahu Model Rancangan 1 (Kiri) Dan Model Rancangan 2 (Kanan) 


\section{f. Konsep Evakuasi Perahu Saat Bencana}

Karakteristik ekologi Kota Manado membuat gelombang pasang menjadi salah satu bencana yang sering menimpa pangkalan perahu yang ada. Upaya yang dilakukan dalam rancangan ini adalah mengadakan pemecah ombak untuk mengurangi energi gelombang yang datang ke pesisir. Berdasarkan analisis, arah datang gelombang tegak lurus dengan garis pantai sehingga pemecah ombak diposisikan sejajar dengan garis pantai.

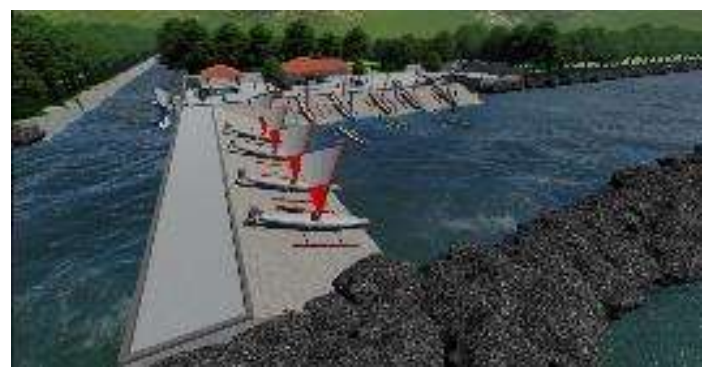

\section{Gambar 23. Pemecah Ombak Di Pangkalan Perahu}

Di samping itu pada rancangan juga dihadirkan ruang evakuasi dan jalurnya yang dekat dengan tambatan perahu agar bisa cepat dijangkau jika signal gelombang pasang sudah menyala. Ruang evakuasi dibuat terbuka dan menyatu dengan ruang reparasi agar pada hari-hari biasa ruangan tersebut tetap dapat difungsikan.

\section{KESIMPULAN}

Rancangan model pangkalan perahu tanggap bencana dengan pendekatan ekokultural ini dibuat berdasarkan hasil penelitian tentang pola aktivitas bermukim dan bernelayan masyarakat. Masyarakat yang kesehariannya beraktivitas di sepanjang kawasan pesisir Kota Manado sudah memiliki alat deteksi gelombang pasang yang dibuat secara tradisional hanya saja beberapa pemecah ombak yang sudah dibangun ternyata belum dapat meminimalisir dampak gelombang pasang dan angin kencang. Belum banyaknya penelitian dan sosialisasi terkait antisipasi dampak gelombang pasang dan angin kencang di kawasan pesisir membuat masyarakat nelayan harus berpikir sendiri cara-cara evakuasi ketika terjadi bencana. Dengan metode penelitian dan pengembangan, hasil penelitian ini dilanjutkan dengan pengembangan desain pangkalan perahu tanggap bencana yang dirancang sesuai kebutuhan masyarakat nelayan setempat. Pendekatan ekokultural diterapkan pada penataan ruang dalam dan ruang luar pangkalan perahu yang juga dapat membantu kelancaran aktivitas bernelayan masyrakat. Modifikasi fasilitas sosial seperti ruang sekretariat dan ruang bersama dapat dimanfaatkan sebagai ruang sosialiasi dari pemerintah dan peneliti bagi masyarakat nelayan. Rancangan pangkalan perahu menghadirkan jalur dan tempat evakuasi saat terjadi bencana dengan desain reling tradisional dengan material bambu pada jalur evakuasi untuk memudahkan perahu-perahu nelayan ditarik ke tempat evakuasi. Tempat evakuasi perahu juga menjadi tempat reparasi perahu sehingga area evakuasi tetap difungsikan meskipun tidak digunakan untuk evakuasi. Hasil simulasi bencana dalam bentuk animasi menunjukkan desain pangkalan perahu yang sudah lebih efektif tanggap dalam menghadapi bencana gelombang pasang dan angin kencang yang sebelumnya sudah dideteksi lewat alat pendeteksi gelombang. Desain pangkalan perahu tanggap bencana baru dapat dilihat dari hasil simulasi namun sudah dapat dinilai keakuratannya saat diimplementasikan di lokasi penelitian memiliki keakuratan kurang lebih $70 \%$ menurut para nelayan dan sejawat. Desain ini menjadi inovasi tanggap bencana dari model rancangan pangkalan perahu dengan pendekatan ekokultural. 
434 Pendekatan Ekokultural pada Model Rancangan Pangkalan Perahu Tanggap Bencana di Kawasan Pesisir Kota Manado - Reny Syafrini, Sangkertadi, Rachmat Prijadi, Valeria Theresia Woy DOI: https://doi.org/10.31004/edukatif.v4i1.1850

\section{UCAPAN TERIMA KASIH}

Ucapan terima kasih disampaikan kepada Universitas Sam Ratulangi.

\section{DAFTAR PUSTAKA}

Amri, U., Ganefri, \& Hadiyanto. (2021). Edukatif : Jurnal Ilmu Pendidikan Perencanaan Pengembangan Dan Pendidikan Berbasis Kearifan Lokal. Edukatif: Jurnal Ilmu Pendidikan, 3(5), 2025-2031.

Boissevain, J., \& Selwyn, T. (2004). Contesting The Foreshore: Tourism, Society And Politics On The Coast. Mare Publication Series No. 2 Amsterdam, 185-204. Https://Doi.Org/10.1515/9789048505340-010

Desfor, G., Laidley, J., Stevens, Q., \& Schubert, D. (2010). Transforming Urban Waterfronts, Fixity And Flow. Routledge.

Frangoudes, K., \& Alban, F. (2005). Fishermen And The Creation Of Marine Parks: Northern Sporades (Greece), Northern Cap De Creus (Catalonia), And The Iroise Sea (France). In Contesting The Foreshore (Pp. 169-184). Amsterdam University Press. Https://Doi.Org/Https://Doi.Org/10.1515/9789048505340-009

Giddens, A. (2010). Teori Strukturasi: Dasar-Dasar Pembentukan Struktur Sosial Masyarakat. Pustaka Pelajar.

Guy, S., \& Farmer, G. (2001). Reinterpreting Sustainable Architecture: The Place Of Technology. Journal Of Architectural Education, 54(3), 140-148. Https://Doi.Org/10.1162/10464880152632451

Hairami. (2019). Bencana Gelombang Pasang, Resiko Yang Harus Diwaspadai. Ivooxid. Https://Ivoox.Id/Bencana-Gelombang-Pasang-Resiko-Yang-Harus-Diwaspadai?Tag_From=Gelombang

Hay, P. P. J., Bacaltchuk, J., Stefano, S., \& Kashyap, P. (2009). Psychological Treatments For Bulimia Nervosa And Binging. Cochrane Database Of Systematic Reviews, 4. Https://Doi.Org/10.1002/14651858.Cd000562.Pub3

Heeg, S. (2010). Flows Of Capital And Fixity Of Bricks In The Built Environment Of Boston: Property-Led Development In Urban Planning? In Transforming Urban Waterfronts, Fixity And Flow (Pp. 275-294). Routledge.

Kurnia, N., Syaifuddin, \& Zain, J. (2019). Tingkat Kepuasan Nelayan Terhadap Pelayanan Jasa Tambat Labuh Di Pelabuhan Perikanan Samudera Bungus. Jurnal Universitas Riau.

Kurniawan, L., Yunus, R., Amri, M. R., \& Pramudiarta, N. (2011). Indeks Rawan Bencana Indonesia.

March, E., \& Springer, J. (2019). Belief In Conspiracy Theories: The Predictive Role Of Schizotypy, Machiavellianism, And Primary Psychopathy. Plos One, 14(12), 1-10. Https://Doi.Org/10.1371/Journal.Pone.0225964

Mcclure, W. R. (2007). Architecture As A Cultural Layer. In The Built Environment: A Collaborative Inquiry Into Design And Planning (Pp. 169-180). John Wiley \& Sons.

Nurjani, E., Rahayu, A., \& Rachmawati, F. (2015). Kajian Bencana Angin Ribut Di Indonesia Periode 19902011: Upaya Mitigasi Bencana. Geomedia: Majalah Ilmiah Dan Informasi Kegeografian, 11(2). Https://Doi.Org/10.21831/Gm.V11i2.3451

Putranto, A. (2020). Tipologi, Dinamika, Dan Potensi Bencana Alam Di Kawasan Pesisir Kabupaten Tulungagung. Ekologia: Jurnal Ilmiah Ilmu Dasar Dan Lingkungan Hidup, 20(1), 14-23. Https://Doi.Org/10.33751/Ekologia.V20i1.1979

Rifaldi, Samudin, M. T., \& Famrizal, A. (2018). The Socio-Economic Life Of The Fishing Community Is In The Area. Jurnal Kolaboratif Sains, 1(1), 1429-1437. 
435 Pendekatan Ekokultural pada Model Rancangan Pangkalan Perahu Tanggap Bencana di Kawasan Pesisir Kota Manado - Reny Syafrini, Sangkertadi, Rachmat Prijadi, Valeria Theresia Woy DOI: https://doi.org/10.31004/edukatif.v4i1.1850

Rohadi, T. (2011). Budaya Lingkungan: Akar Masalah Dan Solusi Krisis Lingkungan. Ecologia Press.

Santoso, D., Yamin, M., \& Makhrus, M. (2019). Penyuluhan Tentang Mitigasi Bencana Tsunami Berbasis Hutan Mangrove Di Desa Ketapang Raya Kecamatan Keruak Lombok Timur. Jurnal Pengabdian Magister Pendidikan Ipa, 2(1). Https://Doi.Org/10.29303/Jpmpi.V1i2.242

Sepriana, R., Sefriani, R., Wijaya, I., \& Lestari, P. (2019). Pengujian Validitas Modul Interaktif Simulasi Dan Komunukasi Digital Berbasis Macromedia Director Mx. Edukatif: Jurnal Ilmu Pendidikan, 1(3), 120 126. Https://Doi.Org/10.31004/Edukatif.V1i3.25

Syafriny, R. (2014). Spatial Conflict On The Urban Coastline: Struggle For Boat Mooring Space Of Littoral Fishermen In Manado, North Sulawesi. Asia Esj 2014: The Asian Symposium On Equity And Social Justice.

Syafriny, R., \& Sangkertadi. (2019). Contested Space In Coastal City. A Case Of Conservation, Community And Tourism Development In Manado - Indonesia. Journal Of Architecture \& Environment, 18(2), 75. Https://Doi.Org/10.12962/J2355262x.V18i2.A3920

Syafriny, R., \& Sangkertadi. (2018). Triad Organik Sebagai Ruang Keberlangsungan Hidup Komunitas Kampung Pantai. Prosiding Seminar Nasional Teknik Arsitektur, Urban \& Permukiman, 193-207.

Syafriny, R., Sangkertadi, S., \& Mastutie, F. (2018). Ketidakseimbangan Distribusi Spasial Di Pesisir Kota Manado. A068-A077. Https://Doi.Org/10.32315/Sem.3.A068

Triana, D., Hadi, T. S., \& Husain, M. K. (2017). Mitigasi Bencana Melalui Pendekatan Kultural Dan Struktural. Seminar Nasional Xii "Rekayasa Teknologi Industri Dan Informasi 2017", 379-384. Https://Journal.Itny.Ac.Id/Index.Php/Retii/Article/View/723

Zamzami, L., \& Hendrawati. (2014). Kearifan Budaya Lokal Masyarakat Maritim Untuk Upaya Mitigasi Bencana Di Sumatera Barat. Jurnal Antropologi: Isu-Isu Sosial Budaya, 16(1), 37. Https://Doi.Org/10.25077/Jantro.V16i1.18 